NBER WORKING PAPER SERIES

\title{
AN INTERNATIONAL COMPARISON OF CAPITAL STRUCTURE AND DEBT MATURITY CHOICES
}

\author{
Joseph P.H. Fan \\ Sheridan Titman \\ Garry Twite \\ Working Paper 16445 \\ http://www.nber.org/papers/w16445
}

\author{
NATIONAL BUREAU OF ECONOMIC RESEARCH \\ 1050 Massachusetts Avenue \\ Cambridge, MA 02138 \\ October 2010
}

This paper has benefited from the useful comments and suggestions provided by Andres Almazan, Heitor Almeida, Lawrence Booth, Stijn Claessens, Joshua Coval, Sudipto Dasgupta, Jay Hartzell, Jiang Luo, Vojislav Maksimovic, Enrico Perotti, Tom Smith, participants at the 2003 European Finance Association Conference, the 2003 Financial Management Association Conference and the 2005 American Finance Association Meeting, seminar participants at the Australian National University, Australian Graduate School of Management, Chinese University of Hong Kong, Hong Kong University of Science and Technology, Shanghai University of Finance \& Economics, University of Melbourne, University of Queensland, University of Sydney, and University of Texas at Austin, and anonymous referees. Joseph Fan thanks the financial support from the Research Grants Council of the Hong Kong Special Administrative Region, China (Project No. CUHK6230/03H) and the University of Queensland for research support during his visit when part of the research was carried out. Garry Twite thanks the financial support from the Australian Research Council Discovery Project (Project ID. DP0664505). The views expressed herein are those of the authors and do not necessarily reflect the views of the National Bureau of Economic Research.

NBER working papers are circulated for discussion and comment purposes. They have not been peerreviewed or been subject to the review by the NBER Board of Directors that accompanies official NBER publications.

(C) 2010 by Joseph P.H. Fan, Sheridan Titman, and Garry Twite. All rights reserved. Short sections of text, not to exceed two paragraphs, may be quoted without explicit permission provided that full credit, including $\odot$ notice, is given to the source. 
An International Comparison of Capital Structure and Debt Maturity Choices

Joseph P.H. Fan, Sheridan Titman, and Garry Twite

NBER Working Paper No. 16445

October 2010

JEL No. G3,G32

\begin{abstract}
This study examines the influence of institutional environment on capital structure and debt maturity choices by examining a cross-section of firms in 39 developed and developing countries. We find that a country's legal and tax system, the level of corruption and the preferences of capital suppliers explain a significant portion of the variation in leverage and debt maturity ratios. Our evidence indicate that firms in countries that are viewed as more corrupt tend to use less equity and more debt, especially short-term debt, while firms operating within legal systems that provide better protection for financial claimants tend to have capital structures with more equity, and relatively more long-term debt. In addition, the existence of an explicit bankruptcy code and/or deposit insurance is associated with higher leverage and more long-term debt. We also find that firms tend to use more debt in countries where there is a greater tax gain from leverage, while firms in countries with larger government bond markets have lower leverage, suggesting that government bonds tend to crowd out corporate debt. Countries with more extensive defined benefit pension funds have higher debt ratios and longer debt maturities, whereas those with more extensive defined contribution fund activities have lower debt ratios. In addition, debt ratios are lower in countries that limit the bond holdings of pension funds. Finally, we do not find a significant association between financing choices and the size of the insurance industry.
\end{abstract}

Joseph P.H. Fan

School of Accountancy

Chinese University of Hong Kong

Shatin, N.T.

Hong Kong SAR

pjfan@cuhk.edu.hk

Sheridan Titman

Finance Department

McCombs School of Business

University of Texas at Austin

Austin, TX 78712-1179

and NBER

titman@mail.utexas.edu
Garry Twite

School of Finance,

Actuarial Studies and Applied Statistics

Australian National University

Canberra ACT 0200

Australia

garry.twite@anu.edu.au 


\title{
An International Comparison of Capital Structure and Debt Maturity Choices
}

\begin{abstract}
This study examines the influence of institutional environment on capital structure and debt maturity choices by examining a cross-section of firms in 39 developed and developing countries. We find that a country's legal and tax system, the level of corruption and the preferences of capital suppliers explain a significant portion of the variation in leverage and debt maturity ratios. Our evidence indicate that firms in countries that are viewed as more corrupt tend to use less equity and more debt, especially short-term debt, while firms operating within legal systems that provide better protection for financial claimants tend to have capital structures with more equity, and relatively more long-term debt. In addition, the existence of an explicit bankruptcy code and/or deposit insurance is associated with higher leverage and more long-term debt. We also find that firms tend to use more debt in countries where there is a greater tax gain from leverage, while firms in countries with larger government bond markets have lower leverage, suggesting that government bonds tend to crowd out corporate debt. Countries with more extensive defined benefit pension funds have higher debt ratios and longer debt maturities, whereas those with more extensive defined contribution fund activities have lower debt ratios. In addition, debt ratios are lower in countries that limit the bond holdings of pension funds. Finally, we do not find a significant association between financing choices and the size of the insurance industry.
\end{abstract}




\section{Introduction}

Corporate financing choices are determined by a combination of factors that are related to the characteristics of the firm as well as to their institutional environment. Although most studies focus on the importance of firm characteristics by examining corporate financing choices within individual countries, ${ }^{1}$ there is a growing literature that considers how institutional differences affect these choices. To explore the cross-sectional variation in the institutional environment, these papers examine capital structure choices across countries (Booth, Aivazian, Demirguc-Kunt, and Maksimovic, 2001; Claessens, Djankov and Nenova, 2001; Demirguc-Kunt and Maksimovic, 1996, 1998, 1999; Giannetti, 2003; De Jong, Kabir and Nguyen, 2008).

This study builds on this recent literature in two important ways. First, because we consider these issues within a panel that includes industry fixed effects, together with firm-level variables, we identify the variation in capital structure across countries that cannot be explained by cross-country differences in the industrial mix and firm-level characteristics. Second, we consider a larger number of countries and a number of important institutional characteristics not previously explored in this literature.

To understand our motivation, it is useful to illustrate the importance of countrylevel factors relative to industry factors in determining capital structure. A regression of firm leverage, measured as the book value of debt over the market value of the firm, on firm-specific variables, industry fixed effects and country fixed effects, has an adjusted R-square of 0.19 . When the regression is estimated with all variables except for country

\footnotetext{
${ }^{1}$ Examples of empirical studies examining the association between firm characteristics and capital structure within specific countries include Titman and Wessels (1988) - U.S., Campbell and Hamao (1995) - Japan and Gatward and Sharpe (1996) - Australia. Barclay and Smith (1995), Stohs and Mauer (1996) and Guedes and Opler (1996) examine the association between firm characteristics and debt maturity in the U.S. Gatward and Sharpe (1996) undertake a similar study of debt maturity in Australia.
} 
fixed effects, the adjusted R-square is reduced to $0.15 .^{2}$ However, in a regression that includes all variables except for industry dummies the adjusted R-square is reduced by only half as much, to 0.17 . When the full regression is estimated with debt maturity, measured as the book value of long-term debt to the book value of total debt, as the dependent variable, the R-square is 0.25 . When the regression is estimated with all variables except for country fixed effects, the R-square is substantially reduced to 0.09. However, in the regression that includes all variables except for industry fixed effects, the R-square is only slightly reduced to 0.23 .

These experiments indicate that the country in which the firm resides is a more important determinant of how it is financed than is its industry affiliation, which in turn suggests that differences in country level institutional factors are likely to have a first order effect on capital structure choices. To examine this possibility in more detail, we estimate a panel regression on a large sample of firms from 39 countries that examines the extent to which cross-country differences in capital structures can be explained by differences in tax policies; legal environment; and the importance and regulation of financial institutions.

Our evidence suggests that the explanatory power of a model that includes between ten and twelve institutional variables explains the cross-section of debt ratios and maturity structures about as well as a model with 39 country dummy variables. These regressions indicate that firms tend to use more debt in countries with a greater tax gain from leverage, which contrasts with Booth, Aivazian, Demirguc-Kunt, and Maksimovic (2001) who, in an earlier study of mostly developing economies, do not find a significant

\footnotetext{
${ }^{2}$ This result is similar in character to a regression reported by Booth, Aivazian, Demirguc-Kunt, and Maksimovic (2001).
} 
relation between debt ratios and tax policy. In addition, we find that the strength of a country's legal system and public governance importantly affect firm capital structure. Weaker laws and more government corruption are associated with higher corporate debt ratios and shorter debt maturity. ${ }^{3}$ We also find that countries with deposit insurance or explicit bankruptcy codes, like the Chapter 11 and Chapter 7 rules in the U.S., have higher debt ratios and longer debt maturities. These findings reinforce the prior literature on the importance of the legal system, the enforcement of investor rights and financial distress resolution (Claessens, Djankov, Mody, 2001; Djankov, Hart, McLiesh and Shleifer, 2008; La Porta, Lopez-de-Silanes, Shleifer, and Vishny, 1997, 1998)

We also find that the preferences of the suppliers of capital influence capital structure choices. ${ }^{4}$ In particular, firms in countries with larger banking sectors have shorter maturity debt, but the association between financing choices and the size of the insurance industry is weak. In addition, firms in countries with higher levels of defined contribution pension fund assets use relatively more equity, while firms in countries with higher levels of defined benefit pension fund assets use relatively more long-term debt, which could reflect differences in how these pension assets are invested. Finally, we find that firms in countries with larger government bond markets have lower debt ratios and shorter maturity debt, indicating that government bonds tend to crowd out long term corporate debt.

The paper is organized as follows: Section 2 discusses the association between country level institutional factors and financial choices. Section 3 introduces the set of

\footnotetext{
${ }^{3}$ This result is consistent with Demirguc-Kunt, and Maksimovic (1999).

${ }^{4}$ One should interpret these results with some caution, because an analysis of capital suppliers does raise endogeneity concerns. In particular, we expect financial institutions to develop in ways that satisfy the financing needs of firms. However, as discussed in Section 2.3, we have selected variables that are less likely to be influenced by the capital structure preferences of corporations.
} 
firm level variables that influence capital structure choice. Section 4 describes the sample. Section 5 presents our results and Section 6 draws some conclusions.

\section{Institutional factors and cross-country determinants of capital structure}

This section discusses how institutional differences between countries can potentially affect how firms within these countries are financed. Specifically, we consider institutional variables that reflect (1) the ability of creditors to enforce legal contracts (2) the tax treatment of debt and equity, and (3) the importance and regulation of financial institutions that represent major suppliers of capital.

We expect that weaker legal systems and weaker public enforcement of laws should be associated with less external equity and shorter maturity debt contracts. We also expect that firms in countries with lower tax preferences for debt will be less levered. Finally, we examine whether the suppliers of capital matter. Although most of the capital structure literature focuses on the financing preferences of firms, at the aggregate level, firm capital structures are determined by the preferences of the suppliers of capital (i.e. investors) as well as the preferences of firms. In particular, exogenous factors that lead suppliers of capital to prefer to hold more or less equity relative to debt will also influence the capital structures of firms.

The following sub-sections introduce the variables that we consider, and discuss how these variables are likely to influence typical debt ratios within our sample of countries. 


\subsection{Legal system}

Incentive problems - conflicts of interest between corporate insiders (managers, employees and/or majority shareholders) and external investors - are important factors that shape corporate policy and productivity. As extensively explored by La Porta, Lopez-de-Silanes, Shleifer, and Vishny (1998), the extent to which contracts can be used to mitigate these problems depends on the legal system, which consists of both the content of the laws and the quality of their enforcement. In the following discussion we will review how these legal factors influence financing choices.

In countries with weak laws and enforcement, financial instruments (e.g. short term debt) that allow insiders less discretion, and are contractually easier to interpret, are likely to dominate. La Porta, Lopez-de-Silanes, Shleifer, and Vishny (1998) find significant variation in the extent of legal protection of external investors across both developed and developing countries, and argue that legal systems based on common law offer outside investors (debt and equity) better protection than those based on civil law, resulting in higher security values (La Porta, Lopez-de-Silanes, Shleifer, and Vishny, 2002). All else equal, this suggests that common law countries will use more outside equity and longer-term debt. To test whether this is the case, we define an indicator variable that takes a value of one if the country's legal system is based on common law and zero otherwise.

In addition to the content of the law, the integrity and enforceability of the law is also important, which we measure by the perceived corruption level in a country. Corruption has been identified as a key factor shaping a country's legal system (Djankov, La Porta, Lopez-de-Silanes and Shleifer, 2003), resource allocation and firm behavior (La 
Porta, Lopez-De-Silanes, Shleifer, and Vishny, 1999; Fisman, 2001; Johnson and Mitton, 2003).

We are not the first to examine the roles of legal factors in corporate financing choices. Demirguc-Kunt and Maksimovic (1999) find that firms have longer duration debt in countries where the legal system has more "integrity". Integrity, measured by a law and order index prepared by the International Country Risk Guide, reflects the extent to which individuals are willing to rely on the legal system to make and implement laws, mediate disputes and enforce contracts. In contrast, we focus on corruption, defined as the abuse of public office for private gain, measured as the Corruption Perception Index (Transparency International), which reflects the extent to which corruption is perceived to exist among public officials and politicians. An advantage of this index is that it provides both time-series and cross-sectional variation; most other measures of integrity, such as the law and order index, do not have comparable historical data.

We reverse the index, so that in our study, it ranges from 0 to 10 , with larger values indicating more severe corruption. In the context of the firm's capital structure choices, the index proxies for the threat of all or part of investor rights being expropriated by managers or public officials. Debt is expected to be used relatively more than equity when the public sector is more corrupt, since it is easier to expropriate outside equity holders than debt holders. Similarly, one can argue that since short-term debt is more difficult to expropriate, it will be used relatively more frequently than long-term debt in more corrupt countries.

Finally, we investigate the enforcement of debt contracts. As identified by Djankov, Hart, McLiesh and Shleifer (2008), the legal structure that specifies the 
resolution of default differs widely across countries. Indeed, in some countries, like the U.S., there is an explicit bankruptcy code that specifies and limits the rights and claims of creditors that facilitates the reorganization of the ongoing business. In contrast, in other countries with no bankruptcy codes or only weakly enforced codes, creditors often have difficulty accessing collateral by liquidating distressed firms or seizing distressed firm assets (Claessens, Djankov, Mody, 2001; Claessens, Djankov, and Klapper, 2003; Claessens and Klapper, 2005; Davydenko and Franks, 2008; Dinc, 2005). With poorly defined bankruptcy procedures, senior lenders typically possess inferior bargaining power relative to the borrower in out-of-court renegotiations due to the weak laws and lenders' inherent information disadvantage about the collateral relative to borrowers (Degryse and Ongena, 2005; Petersen and Rajan, 1994) lowering demand for long-term debt. On the borrower side, the existence of defined bankruptcy procedures for corporate reorganization and the deferral of debt payments increase the incentive for firms to issue long term debt since a default can be less onerous. ${ }^{5} \mathrm{We}$ conjecture that the lack of explicit bankruptcy codes and enforcement discourage the use of debt, in particular long-term debt. Based on Djankov, Hart, McLiesh and Shleifer (2008), we define an indicator variable that takes a value of one for those countries in which an insolvent firm can undergo a court supervised reorganization proceeding.

\subsection{Tax code}

The tax system in general, and specifically the tax treatment of interest and dividend payments, has been recognized as an important factor influencing capital structure

\footnotetext{
${ }^{5}$ The influence of the existence of a bankruptcy code on both investor demand for, and corporate supply of long-term debt was pointed out to the authors by an anonymous referee.
} 
choices since the seminal work of Modigliani and Miller (1963). ${ }^{6}$ We observe three main categories of tax regimes:

The first is the classical tax system in which dividend payments are taxed at both the corporate and personal levels and interest payments are tax-deductible corporate expenses. The classical tax system exists in Brazil, Chile, China, Hong Kong, India, Indonesia, Israel, Japan, Korea, Malaysia, Netherlands, Pakistan, Peru, Philippines, Singapore, South Africa, Switzerland, United Kingdom (post 2000) ${ }^{7}$ and the United States.

The second is the dividend relief tax system, where dividend payments are taxed at a reduced rate at the personal level. A dividend relief tax system exists in Austria, Belgium, Denmark, Greece, Portugal, Sweden, Thailand and Turkey. ${ }^{8}$ In Greece and Turkey dividend payments are not taxed at the personal level, that is, a full dividend relief system.

Third is the dividend imputation tax system, where corporations can deduct interest payments, but where the domestic shareholders of a corporation receive a tax credit for the taxes paid by the corporation. The goal of the system is to tax corporate profits only once. Dividend imputation systems are in place in Australia, Canada, France, Germany, Ireland, Italy, Mexico, New Zealand, Norway, Spain, Taiwan and United Kingdom (pre 2001). The proportion of corporate tax available as a tax credit under these imputation systems varies from country to country. In Australia, Finland, Germany, Italy, New Zealand and Norway the full amount of the corporate tax paid is

\footnotetext{
${ }^{6}$ See Graham (2003) for a review of the literature on the influence of taxes on capital structure choice.

${ }^{7}$ The United Kingdom reverted to a classical tax system in 2001.

${ }^{8}$ The United States currently provides preferential tax treatment for dividend over interest payments, but not in our sample period.
} 
distributed as a tax credit. In other countries only part of the corporate tax credits are distributed.

All else equal, we expect that debt will be used less in countries with dividend imputation or tax relief systems than in countries with classical tax systems that double tax corporate profits. To test for this relationship for each country in our sample, we estimate the tax shield, using the tax gain from leverage variable introduced in Miller (1977):

$$
1-\frac{\left(1-\tau_{c}\right)\left(1-\tau_{e}\right)}{\left(1-\tau_{i}\right)}
$$

where $\tau_{c}$ is the statutory corporate tax rate, $\tau_{i}$ is the highest statutory personal tax rate on interest income and $\tau_{e}$ is the highest effective personal tax rate on equity income coming from dividends. ${ }^{9}$

The tax gain from leverage can take both positive and negative values. Negative values arise under a dividend relief tax system, when the personal tax rate on interest income is greater than the corporate tax rate and the personal tax rate on dividend income is less than the corporate tax rate. This is the case under a full dividend relief system as exists in Greece and Turkey, as well as under some partial relief countries like Belgian and Thailand The tax gain from leverage is zero under a full dividend imputation tax system, which is the case in Australia, Germany, Italy, New Zealand and Norway. For all other countries the value of the tax gain from leverage is positive.

\footnotetext{
${ }^{9}$ We also consider a dividend tax indicator variable that takes a value of one for countries with either a full dividend relief tax system or a full dividend imputation tax system and zero otherwise.
} 


\subsection{Suppliers of capital}

Financial economists have typically viewed the capital structure problem from the perspective of firms that face competitive and complete financial markets, where debt and equity capital are offered at equivalent risk-adjusted rates. However, when this is not the case, the preferences of investors to hold debt versus equity instruments will have an influence on how firms are financed. For example, in the Miller (1977) model, the aggregate debt ratio in the economy is determined by aggregate investor preferences for holding debt versus equity securities. While these preferences are determined by taxes in Miller's model, one can more generally consider how investor preferences for holding various debt and equity instruments affect the capital structure choice of firms. ${ }^{10}$

We will specifically consider the preferences of banks, pension funds and insurance companies. Banks tend to have short-term liabilities and thus may have a comparative advantage holding short-term debt. In contrast, pension funds have longterm liabilities, and thus have a preference for holding long term assets. Likewise, insurance companies tend to hold longer term assets. Hence, we might expect firms in counties with a larger banking sector to use more short-term financing and firms in countries with larger pension funds and insurance sectors to use more long-term financing.

The analysis of supply effects raise endogeneity concerns, since we expect financial intermediaries to develop in ways that satisfy the financing needs of firms as well as the preferences of investors. Existing studies (for example, Dermirguc-Kunt and Maksimovic, 1999; De Jong, Kabir and Nguyen, 2008) examine the effects of stock/bond

\footnotetext{
${ }^{10}$ See Titman (2002) for a discussion of the effect of investor preferences on capital structure choices.
} 
market size, turnover and bank total assets on capital structure choices. These variables, however, are likely to be influenced by the capital structure preferences of corporations. For example, in countries with industries (like high tech) that require considerable amounts of external capital, the stock market is likely to be larger. ${ }^{11}$ With this in mind, we depart from the existing literature and select proxies that are not likely to be directly influenced by the capital structure preferences of corporations. In particular, we select measures of the supply of funds available to these financial intermediaries.

To proxy for the supply of funds to banks, we use deposits/GDP to measure the amount of funds that are available to the banking sector. ${ }^{12}$ In addition, deposit insurance is used in many countries to protect bank depositors, in full or in part, from losses caused by a bank's inability to pay its debts when due. This lowers the risk of bank runs, reducing the banks need to hedge and seek more liquid short-term debt. We conjecture that the existence of deposit insurance will influence the lending and maturity choices of banks. In particular, banks provide more credit to firms and lend longer term debt when deposits are protected. Hence, one might expect that firms in countries with deposit insurance to have higher leverage and more long-term debt. To test this relationship, we utilize a deposit insurance indicator variable that takes a value of one if bank deposits are

\footnotetext{
${ }^{11}$ Demirguc-Kunt and Maksimovic (1999) recognise this endogeneity issue and address it by using a twostage instrumental variable regression. They chose as instruments measures of the size of the economy and the flow of funds, plus proxies for the content, strength and integrity of the legal system. However, one can argue that these variables either directly influence the capital structure choice or are potentially influenced by the types of firms in the economy, and are thus indirectly related to the capital structure choice.

${ }^{12}$ It is possible that there are unobserved factors that affect both the willingness of investors to deposit funds with banks and the willingness of banks to provide long-term funding to firms, creating a spurious relation between deposits and capital structure. For example, one can argue that the financing needs of corporations affect the funds that are available to the different investor sectors. Suppose, for example, that the need for monitoring declines, making bank loans somewhat less attractive to long-term bonds. On the margin, this would increase the interest rate on long-term bonds, making it more attractive for households to invest in fixed income mutual funds rather than bank deposits. While this creates a potential endogeniety problem, it is mitigated by the inclusion of our institutional variables and probably has a minor influence on our estimates.
} 
at least partially explicitly insured by government and zero otherwise (Demirguc-Kunt, Karacaovali and Laeven, 2005).

We use insurance penetration (value of total insurance premiums (life and nonlife)/GDP) to measure the amount of funds that are available to insurance companies. Different insurance companies, however, may have very different liability structures and may thus have different preferences for the assets that they hold. For example, life insurance companies that offer contracts with a substantial savings component, such as whole life contracts, might have a preference for long term debt. In contrast, insurance companies that offer term life and property and casualty insurance tend to have shorterterm obligations, and thus, are expected to hold shorter-term debt. Unfortunately, we do not have data that allows us to distinguish between the different sectors of the insurance industry.

We measure pension fund penetration separately as the value of defined benefit pension fund assets over GDP and the value of defined contribution pension fund assets over GDP. This distinction may be important because in firms with defined benefit plans, the asset allocation is determined by the plan sponsors, while with defined contribution plans, the asset allocation is made by individuals. It should also be noted that defined benefit pension plans are often underfunded, creating a liability that we do not observe in our data set.

In addition, since it is possible that cross-country differences in pension fund regulations influence the investment choices of pension funds, we also examine restrictions on debt and equity holdings of pension funds. We conjecture that the relative restrictions on debt and equity holdings will influence the choice between debt and 
equity. In particular, pension funds will hold more equity when restrictions on bond holdings are tighter relative to those on equity holdings. Hence, one might expect that firms in countries with tighter restriction on bond holdings to issue more equity. To investigate this possibility we estimate an index of relative restrictions on debt and equity holdings measured as the ratio of the proportional limit on equity holdings over the proportional limit on debt holdings taken from the Survey of Investment Regulation of Pension Funds, OECD. For each year we ranked countries by their pension fund regulation index, assigning countries into quartiles. We assigned a score of 1 to 4 to the quartiles, with larger values indicating tighter restriction on bond holdings.

An alternative measure of the supply of funds available to financial intermediaries is the level of domestic savings, which we measure as gross domestic saving over GDP. In addition, we examine the size of the government bond market in each country by including domestically denominated government bonds/GDP as an independent variable. Government bonds can influence the supply of debt capital that is available to the corporate market for two reasons. The first is a simple crowding out argument. If there is a fixed supply of debt capital, then government debt can compete for that fixed supply and leave less available for corporate borrowers. The second possibility is that the supply is not fixed, and that the presence of government borrowers can help the debt market develop, increasing the demand for corporate debt.

\section{Firm level characteristics and capital structure choice}

Consistent with the existing literature (Titman and Wessels, 1988; Guedes and Opler, 1996; Rajan and Zingales, 1995) we include a set of firm level variables that 
capture factors that are known to affect leverage and maturity structure. These variables include asset tangibility (fixed assets over total assets), profitability (net income over total assets), firm size (natural logarithm of total assets) and the market-to-book ratio (market value of equity over book value of equity). Due to data limitations in some of the countries included in our study, we do not include variables that measure the effective tax rate, operating risk, research and development expenditure, capital expenditure and selling expenses as per Titman and Wessels (1988). In place of these variables we include the market-to-book ratio, which can proxy for growth as well as the collateral value of assets, and industry indicator variables based on two-digit SIC codes. ${ }^{13}$

\section{Data and sample}

This section describes the sample and presents the country and industry patterns of capital and debt maturity structures. It then introduces the empirical procedure employed in this study.

\subsection{Sample selection}

The primary source of our firm-level data is Worldscope, which contains financial data on companies from a wide range of industries in over 50 countries. We restrict the sample to those firms listed on the stock market of the country in which it is domiciled.

Our analysis covers the period of 1991 through 2006. We exclude firm-year observations with missing financial data that is required for the firm-level analysis. The final sample consists of 36,767 firms from 39 countries, totalling 272,092 firm-years.

\footnotetext{
${ }^{13}$ See MacKay and Phillips (2005) for evidence on the importance of industry fixed effects.
} 
Table 1 provides a description of the sample, which covers a broad cross section of developed and developing countries with every continent represented. Most of the countries have observations in each of the 16 years.

As can be seen from the last two columns of Table 1, the coverage of the sample firms varies across countries in terms of number and/or market capitalization, reflecting that Worldscope has uneven coverage of firms across the countries. For most of the economies we have more than 60 percent of sample coverage in terms of market capitalization and 50 percent in terms of number of listed firms. The economies with lower data coverage tend to be developing economies.

[Table 1 about here]

\subsection{Country financing patterns}

Our measures of capital structure are:

(i) leverage, measured as the proportion of total debt to market value of the firm (total debt/market value). Total debt is defined to be the book value of shortterm and long-term interest bearing debt. Market value of the firm is defined as the market value of common equity plus book value of preferred stock plus total debt, or

(ii) debt maturity, measured as the proportion of the book value of long-term debt to total debt (long-term debt/total debt). ${ }^{14}$

To gain a basic idea about how capital and maturity structures differ across countries, we compute the median leverage and maturity structure by country for the period 1991 to

\footnotetext{
${ }^{14}$ Trade credit is an important source of financing in economies with underdeveloped financial institutions (Demirguc-Kunt and Maksimovic, 2001; Fisman and Love, 2003). Our results are robust to including trade credit (measured as accounts payable) in our measure of short-term debt.
} 
2006. As can be seen in Figure 1, developing economies occupy both ends of the leverage spectrum. The highest five leverage ratios are observed in South Korea, Indonesia, Brazil, Portugal, and Pakistan, while the lowest five are observed in Australia, South Africa, Canada, the United States, and Turkey. Developing economies seem to dominate the higher range, while developed economies tend to be at the lower range. The median leverage ratio for the developing economies in the sample is $0.26,{ }^{15}$ while for the developed economies the median leverage ratio is 0.20 . The middle range of the leverage spectrum is mixed with both developing and developed economies.

[Figure 1 about here]

Figure 2 presents the median maturity structure by country. It is clear from the figure that debt obligations have longer maturities in more developed economies. The five countries with the highest long-term debt ratios are New Zealand, Norway, Sweden, USA, and Canada. The lowest five median long-term debt ratios are observed in China, Greece, Turkey, Taiwan, and Thailand. ${ }^{16}$ The median long-term debt ratio for the developing economies in the sample is 0.36 , while for the developed economies the median long-term debt ratio is 0.61 .

[Figure 2 about here]

In addition to the set of firm and country-level variables described in Section 2, we include inflation, inflation volatility (measured as the standard deviation of inflation rates over the preceding four years) and a developed economy indicator variable that takes a value of one if the country is classified as a developed economy according to the

\footnotetext{
${ }^{15}$ Economies within the sample classified as developing, according to the World Bank, are Brazil, Chile, China, India, Indonesia, Malaysia, Mexico, Pakistan, Peru, Philippines, Taiwan, Thailand, Turkey and South Africa.

${ }^{16}$ This parallels the findings of Demirguc-Kunt and Maksimovic (1999) for an early sample period, 19801991.
} 
World Bank classification that is based on the countries' gross national income levels. ${ }^{17}$ Inflation is included because debt contracts are generally nominal contracts and high inflation, which is generally associated with high uncertainty about future inflation, may tilt lenders away from long-term debt. Likewise, higher inflation volatility reflects higher uncertainty about future inflation, tilting lenders away from long-term debt. A developed economy indicator variable is included because it may pick up an element of economic development that is not already captured by our other variables. Both firm and country level variables are lagged one period to allow for the non-contemporaneous nature of the interaction between firm/country level characteristics and financing choices.

Table 2, which presents the summary statistics, shows cross-sectional variation in the country-level variables. The country-level variables are defined in Appendix 1, along with their data sources. Except for the common law, developed economy, bankruptcy code and deposit insurance variables that are constant across time, all remaining variables exhibit time-series variation. ${ }^{18}$ Appendix 2 reports the country-bycountry median values of the country-level explanatory variables.

[Table 2 about here]

To gain a basic understanding of how debt ratios and maturity structures are influenced by these variables, we compute the Pearson correlation coefficients for pairs of the dependent and independent variables. The results, reported in Table 3, suggest that the legal system, the tax system, and the suppliers of funds potentially influence the capital structure choice. In particular,

\footnotetext{
${ }^{17}$ The set of country level independent variables are defined in Appendix 1, along with their data sources.

18 The corruption index prior to 1995 is taken as the 1988-1992 composite level, because compatible annual data is not available prior to 1995.
} 
- firms in more developed economies have lower debt ratios and more longterm debt;

- common law is associated with lower leverage and more long-term debt;

- low levels of corruption are associated with lower debt ratios and a greater use of long-term rather than short-term debt;

- the existence of an explicit bankruptcy code is associated with higher debt ratios and a greater use of long-term debt;

- firms in countries that have a higher tax preference for debt have higher debt ratios;

- firms in countries with more bank deposits and larger domestic savings tend to have higher leverage and more short-term debt;

- the existence of explicit deposit insurance is associated with more longterm debt;

- the level of defined contribution pension fund assets is associated with lower leverage; and

- the level of defined benefit pension fund assets is associated with the use of long-term debt. ${ }^{19}$

[Table 3 about here]

\footnotetext{
${ }^{19}$ In unreported analysis we examined these correlations in a number of subsamples. Specifically, we separately examine developed and developing economies, and we divide the sample between two time periods, 1991-1998 and 1999-2006. There are some differences between the subsamples. For example, we find that the correlation between leverage and common law is strong only in developed economies and taxes and deposit insurance are strongly correlated with leverage in only the initial sub-period. In addition, the size of the government bond market is negative and highly correlated with leverage in developing economies, but only in the initial sub-period. Deposit insurance is positively correlated with debt maturity in only the later sub-period while insurance penetration is positively correlated with debt maturity in both sub-periods, but only in developing economies. Finally, the size of the government bond market is negative and strongly correlated with debt maturity in the later sub-period but only in developed economies.
} 
To investigate whether these variables are likely to be subject to collinearity problems in our later regression analysis, we examine the correlations between the independent variables that are used in our analysis. From Table 3, we see that most variables are not highly correlated with each other, with some notable exceptions. In particular, the correlation between the economic development indicator variable and the corruption index is negative 76 percent.

\section{Regression analysis}

This section presents regressions that estimate the influence of country-level explanatory variables on capital structure choices controlling for firm- and industry-level characteristics. Our regressions are estimated with a General Methods of Moments (GMM) approach that accounts for the fact that the regression residuals are heteroskedastic and serially correlated across both firm and country level observations. ${ }^{20}$

\subsection{The determinants of leverage}

Table 4 presents the results of the leverage regressions. ${ }^{21}$ Column one reports the regression for the full sample, column two provides evidence for the sub-sample of developed economies only and column three the sub-sample of developing economies only. Columns four and five provide evidence for the sub-periods, 1991-1998 and 1999-

\footnotetext{
${ }^{20}$ The regressions are performed on panel data where the residuals may be correlated across firms and/or across country, and OLS standard errors can be biased. We use the ordinary least square (OLS) method with heteroscedastic / autocorrelation corrected (HAC) errors (Andrew, 1991) and clustered at the country level (Petersen, 2008). The HAC procedure accounts for the potential heteroscedasticity and autocorrelation at the firm level by deriving the t-statistics of estimated OLS coefficients from Generalized Methods of Moments (GMM) standard errors corrected for heteroscedasticity and auto-correlation.

${ }^{21}$ The results are robust to the use of alternative proxies for the country's legal system, corruption, taxation and financial market development. Alternative proxies leave unaffected other estimated coefficients. In addition, results are substantially unchanged when we winsorize all variables at the 1 percent level.
} 
2006, respectively, and Column six provides evidence for a sub-sample representing OECD countries for which pension fund bond/equity holding restriction information is available. Column seven provides evidence for a select sub-sample of OECD countries for which pension fund asset information is available.

[Table 4 about here]

\subsubsection{Firm effects}

The top half of Table 4 reports the coefficient estimates of our firm-specific variables. These coefficient estimates indicate that leverage is positively related to asset tangibility and firm size and negatively related to profitability, and the market-to-book ratio. These results, which hold in the full sample as well as the sub-samples, are consistent with evidence on U.S. firms (Bradley, Jarrell, and Kim, 1984; Titman and Wessels, 1988) and more recent international evidence (Rajan and Zingales, 1995 and Booth, Aivazian, Demirguc-Kunt, and Maksimovic, 2001; De Jong, Kabir and Nguyen, 2008). These results are also generally consistent with individual country leverage regressions that we report in Appendix 3. The coefficients for the market-to-book ratio have the same sign in all country regressions. Asset tangibility and size are positively related to leverage in 38 and 34 out of 39 countries, respectively. Finally, profitability is negatively related to leverage in 36 out of 39 countries.

\subsubsection{Country effects}

The lower half of Table 4 reports coefficient estimates for country variables. The regression for the full sample (Column 1) has an adjusted R-square of 0.1798 which is the 
same order of magnitude as the preliminary result reported previously, regressing leverage on firm-specific variables, industry and country fixed effects.

These coefficient estimates indicate that leverage is positively related to economic development, but unrelated to both inflation and inflation volatility. Consistent with better investor protection leading to a greater use of equity financing, we find that corruption is associated with higher debt ratios, common law systems are associated with lower debt ratios and the existence of an explicit bankruptcy code is associated with higher debt ratios. ${ }^{22}$ In addition, we find that leverage is higher in countries where the tax gain from leverage is positive. This evidence contrasts with Booth, Aivazian, DemirgucKunt, and Maksimovic (2001) who do not find a significant relation between debt ratios and tax policy. This difference in results arises because of differences in both the sample countries and sample periods. The Booth, Aivazian, Demirguc-Kunt, and Maksimovic (2001) sample is mainly developing economies over the period 1980 to 1991 . As we show, our evidence in favor of a tax effect comes from developed economies in a later time period.

We find some support for the idea that suppliers of capital influence firm debt ratio choices. In particular, we find that leverage is higher in countries with deposit insurance, suggesting that the banking industry is important, but we do not find a significant relation between the size of the banking sector and debt ratios. In addition, we do not find a significant relation between leverage and the size of the insurance industry,

\footnotetext{
${ }^{22} \mathrm{We}$ also considered the possibility that in some countries regulatory barriers to entry might decrease the risk of incumbent firms and thereby increase their debt capacities. To examine this in more detail, we considered regulatory variables introduced in Djankov, La Porta, Lopez de Silanes and Shleifer (2002). However, because these variables are highly correlated with corruption and our common law indicator variable, we did not include them in the regression reported in Table 4. The high correlation between these entry barrier variables and common law and corruption, however, may partially explain why common law and corruption have such a strong effect on the capital structure choice.
} 
the level of domestic savings or the size of the government bond market. ${ }^{23}$ However, in a select sample of OECD countries that report the level of pension fund assets we find that firms in countries with larger defined benefit pension funds have higher debt ratios and those with larger defined contribution pension funds have lower debt ratios.

There are some significant differences between the subsamples. In particular, common law and the bankruptcy code are significant in the sample of developed economies, but not in the sample of developing economies; while deposit insurance and the size of the government bond market are important in developing economies, but not in developed economies.

In addition, we find that the level of domestic savings and the size of the government bond market are significant in the 1991-1998 sub-period, but not in the 19992006 sub-period, while taxes and deposit insurance are important in the later time period, but not in the former period. The negative association between leverage and the size of the government bond market in the 1991-1998 sub-period suggests that there may be a fixed demand for fixed-income securities, so that government bonds crowd out corporate bond issues.

The subsample analysis reveals that corruption is consistently associated with higher debt ratios in all subsamples. However, the common versus civil law distinction is less important in developing economies. On the other hand, deposit insurance is

\footnotetext{
${ }^{23}$ The weak result with respect to insurance penetration may be due to the lack of a clear prediction as to the association between leverage and insurance penetration. Recognizing that life insurance incorporates both a savings (whole life and annuities) and an insurance (term insurance) product, we follow Beck and Webb (2003) and the suggestion of an anonymous referee, and proxy for the size of the insurance sector as a savings vehicle using insurance premiums/domestic savings. However, as with insurance penetration, we do not find a significant relation between leverage and insurance premiums/domestic savings.
} 
significant in the latter time period, reflecting, perhaps, an increase in the number of countries adopting explicit deposit insurance from 23 to 33 .

Taxes are significant in the sample of developed economies, but not in the sample of developing economies, and only in the later time period. This may be due to the observation that the influence of corporate taxes is likely to be weaker in countries where they are easier to evade. ${ }^{24}$ In unreported regressions, we find that taxes are significant in a sample of below median tax evasion countries, but not in a sample of above median tax evasion countries. ${ }^{25}$ With this index, our entire sample of developing economies is characterized as high tax evasion countries.

In addition, we consider an alternative tax measure that considers only the tax treatment of dividends. As discussed in footnote 9, we estimate a dividend tax indicator variable that takes a value of one for countries with either a full dividend relief tax system or a full dividend imputation tax system and zero otherwise. With this measure we find that leverage is lower in countries that tax dividends less, and this result holds strongly in all subsamples and sub-periods.

Finally, we find that the coefficients of inflation volatility, which are insignificant in about half the regressions, is significantly positive in the developed country subsample, the subsample of OECD countries for which pension fund asset information is available and in the total sample of countries in the 1999-2006 sub-period. We also find negative associations between leverage, the size of the banking sector and the existence of deposit

\footnotetext{
${ }^{24}$ The likelihood that the potential to avoid paying taxes influences the strength of the relationship between taxes and leverage was pointed out to the authors by an anonymous referee

${ }^{25}$ Based on the World Bank tax evasion index, World Economic Forum, Global Competitiveness Report $2001 / 2002$.
} 
insurance in the developed economy subsample. These latter two findings are inconsistent with our expectations, but appear to be driven by outliers. ${ }^{26}$

\subsection{Determinants of maturity structure}

\subsubsection{Firm effects}

Table 5 reports the results of the debt maturity structure regressions. ${ }^{27}$ These regressions are estimated on the full sample and the sub-samples as previously discussed. Column one reports the regression for the full sample, column two provides evidence for the subsample of developed economies only and column three the sub-sample of developing economies only. Columns four and five provide evidence for the sub-periods, 1991-1998 and 1999-2006, respectively. Column six provides evidence for sub-sample representing OECD countries for which pension fund asset information is available.

[Table 5 about here]

The coefficients of the firm-specific variables are largely consistent with prior research (Barclay and Smith, 1995; Stohs and Mauer, 1996; Guedes and Opler, 1996; Demirguc-Kunt and Maksimovic, 1999) in the full sample and all sub-samples and subperiods. Long-term debt is used more by firms with greater asset tangibility, larger size and higher profits. However, in contrast to the findings in the U.S., we find that the

\footnotetext{
${ }^{26}$ In particular, the high leverage ratios of South Korean firms generate the relation between leverage and inflation volatility, deposits and deposit insurances in both the developed economies subsample and the 1999-2006 sub-period. South Korea is characterised by high inflation volatility, a relatively small banking sector, the existence of deposit insurance and a relatively high level of domestic savings. After dropping South Korea, inflation volatility, the size of the banking sector and deposit insurance are all insignificantly related to leverage.

${ }^{27}$ The results are robust to the use of alternative proxies for the country's legal system, corruption, taxation and financial market development. In addition, results are substantially unchanged when we winsorize all variables at the 1 percent level.
} 
market-to-book ratio is only weakly associated with debt maturity in the full sample and is unrelated to debt maturity in the developed economy subsample.

Appendix 4 reports the results of the country-by-country debt maturity regressions. The most robust cross-sectional determinant of debt maturity is asset tangibility. With one exception, asset tangibility is significantly positively related to debt maturity structure. On the other hand, we find cross-country variation in the signs of the estimated coefficients for profitability, firm size and the market-to-book ratio. Profitability is positively related to debt maturity structure in 25 (statistically significant in 15) out of 39 countries. Firm size is is positively related to debt maturity structure in 33 (statistically significant in 21) out of 39 countries and the market-to-book ratio is positively related to debt maturity structure in 28 out of 39 countries and is statistically insignificant in most countries. Indeed, this relation is significantly negative only in the U.S. $^{28}$

\subsubsection{Country effects}

The estimates of the country level coefficients reveal that debt maturity is negatively related to the level of corruption, but positively related to the common law indicator variable, consistent with lower corruption and stronger investor protection encouraging the use of long-term debt financing. Also, the existence of an explicit bankruptcy code is associated with greater use of long-term debt. We find that debt maturity is positively related to the level of economic development. Overall our results

\footnotetext{
${ }^{28}$ Prior literature also report mixed results. For example, Guedes and Opler (1996) report negative relations for U.S. firms, while Stohs and Mauer (1996) find only mixed support for an inverse relationship for U.S. firms. Ozkan (2000) reports a positive relationship for U.K. firms. Outside the U.S. and the U.K., international evidence generally does not find significant relation between the two variables (Antoniou, Guney, and Paudyal, 2006; Terra, 2005).
} 
with respect to the relation between maturity structure and country level characteristics are more robust than those reported for leverage.

Consistent with the preferences of the suppliers of capital having an influence on the firms' maturity structures, we find that debt maturity is strongly negatively related to the amount of deposits in the country's banking sector. This is in contrast to the negative, but insignificant banking sector result reported by Demirguc-Kunt and Maksimovic (1999). Further, we find that the level of domestic savings, measured as gross domestic saving over GDP, is negatively related to debt maturity. We also find that debt maturity is longer in countries with explicit deposit insurance reflecting the willingness of banks to lend longer-term debt when deposits are protected. In addition, debt maturity is shorter, the larger the government bond market. However, we find no reliable relation between maturity structure and the degree of insurance penetration. The weak result with respect to insurance penetration may be due to the lack of a clear prediction as to the association between maturity and insurance penetration. ${ }^{29}$

In general, although the results in all subsamples and sub-periods are similar, there are several exceptions. Inflation rate volatility is associated with shorter maturity in developed economies, but unrelated to maturity in developing economies. The size of the insurance industry is positively related to maturity in developing economies, but unrelated to maturity in developed economies. In addition, deposit insurance is associated with longer debt maturity only in the latter time period, possibly due to an increase in the number of countries adopting explicit deposit insurance from 23 to 33 over the full sample period. The size of the government bond market is negatively related to maturity

\footnotetext{
${ }^{29}$ As noted previously, we include a proxy for the size of the insurance sector as a savings vehicle using insurance premiums/domestic savings. However, as with insurance penetration, we do not find a significant relation between maturity and insurance premiums/domestic savings.
} 
only in developed economies and the relation is significant only in the latter time period. In addition, for a subsample of OECD countries we find that the level of defined benefit pension fund assets is associated with greater use of long-term debt, while the level of defined contributions pension fund assets is unrelated to debt maturity. Finally, we find a significant positive relation between debt maturity and inflation in the developing economy subsample, in the earlier time period, and in the OECD subsample. ${ }^{30}$

\subsection{Fixed-Effects and Cross-Sectional Estimates}

This section examines the extent to which the cross-sectional and time-series variation in our explanatory variables drive our results. Up to this point our emphasis has been on the cross-sectional variation in capital structures. However, the debt ratios in individual countries also vary from year to year, and some of that year to year variation may be explained by the year to year changes in our explanatory variables.

To estimate the extent to which our results are generated from the cross section versus the time series we estimate both firm/country fixed-effects and Fama-MacBeth (1973) regressions. Specifically, we report fixed-effects leverage and maturity structure regressions in columns one and two of Table 6, respectively. The Fama-MacBeth (1973) leverage and maturity structure regressions with Newey-West corrected standard errors are reported in columns three and four, respectively. By sweeping out individual firm and country-effects, the fixed-effects regression estimates the extent to which the timeseries variation of our independent variables explains the time-series of capital structure choices. In contrast, the Fama-MacBeth (1973) regression estimate the regression model

\footnotetext{
${ }^{30}$ The result that inflation is positively related to debt maturity in both developing economies and the earlier time period is generated by the low inflation/short-term maturity characteristic of China. After dropping China, inflation is insignificantly related to maturity.
} 
for each of the 16 years in sample period and then average the coefficients for all independent variables across the 16 years, isolating the cross-sectional determinants of capital structure. The coefficients and statistical significance of the independent variables are similar to those reported in the cross-sectional, time series regressions (Tables 4 and 5).

[Table 6 about here]

The regression estimates reported in Table 6 indicate that the relationships between financing choices and firm characteristics are significant in both the time-series and the cross-section, and are consistent with our earlier estimates. However, the results of the inflation and financial institution variables continue to be mixed. The results also show that several country variables, in particular corruption and deposit insurance, have significant effects on firm capital structure choices even though their time-serial variations are small.

\subsection{Book values and financing choices}

In this section we examine how the country variables affect the levels of short-term debt, long-term debt, and total debt relative to the asset values of the firms in our sample. We measure book leverage as the proportion of total debt to total assets of the firm, decomposing this measure into short-term debt to total assets and long-term debt to total assets.

[Table 7 about here]

Table 7 presents the results of the book leverage regressions. Column one reports 
the regression for total book leverage, column two provides evidence for the long-term debt ratio and column three provides evidence for the short-term debt ratio. As this table illustrates, the long-term debt ratio is higher in more developed economies, countries with common laws, lower corruption, explicit bankruptcy codes, relatively smaller banking sectors, deposit insurance, lower domestic savings, and smaller government bond issuances. By contrast, the short-term debt ratio is higher in less developed economies, countries not under common laws, countries with higher corruption, higher domestic savings, larger banking sectors, lack of deposit insurance, and higher domestic savings. Taken together, these results of the long- and short-term debt regressions are consistent and complementary with the results of the debt maturity ratio regressions in Table $5 .{ }^{31}$

\section{Summary and Conclusion}

At the outset, we described regression results that indicate that a firm's capital structure is determined more by the country in which it is located than by its industry affiliation, suggesting that the institutional environment can have a profound effect on how firms are financed. Specifically, we find that a country's legal and taxation system, level of corruption and the preferences of capital suppliers - banks and pension funds - explain a significant portion of the variation in leverage and debt maturity ratios.

\footnotetext{
$31 \mathrm{We}$ also find that inflation rate volatility is associated with lower total debt ratio, which is in contrast to the previous results in Table 4, where leverage is measured as total debt to market value. Note also that the size of the banking sector is associated with lower total debt ratio. However, this result is driven by the high leverage ratios of South Korean firms and relatively small banking sector of the South Korean economy. After dropping South Korea the size of the banking sector is insignificantly related to book leverage. Interestingly, the results presented in Table 7 indicate that the relationship between financing choices and tax is more important when leverage is defined relative to total assets rather than the market value of the firm.
} 
The effects of taxes on capital structure choices are consistent with theory. When the tax gain from leverage is positive, firms tilt their capital structures towards more debt. However, as we note below, the tax effect is not as strong and pervasive as other influences on capital structure. The legal environment also has an important influence on capital structure choices. Our strongest finding is that firms in countries that are viewed as more corrupt tend to be more levered and use more short-term debt. We also find that common law countries have lower leverage and use more long-term debt and that firms in countries with an explicit bankruptcy code have higher leverage and use relatively more long-term debt.

We also provide evidence that suppliers of capital can influence how firms are financed. Most notably, the debt maturity structure of corporations in countries with larger banking sectors tend to be shorter, reflecting the preferences of banks to lend shortterm. However, controlling for the size of the banking sector, firms in countries with deposit insurance tend to have longer maturity debt, suggesting that deposit insurance in some way facilitates long term lending by banks. In contrast, our evidence of a relation between the size of the insurance sector and capital structure is very weak. However, we find that firms in countries with higher levels of defined contributions pension fund assets use relatively more equity, while firms in countries with higher levels of defined benefit pension fund assets use relatively more long-term debt. In addition, we find evidence that a larger government bond sector crowds out private debt capital in the developing countries, leading firms in these countries to borrow less. We do not, however, find an effect of government borrowing on debt/value ratios of firms in developed countries, but 
we do find that firms in these countries tend to have shorter maturity debt when the government bond market is larger.

While not all of our results hold across all subgroups and sub-periods, some of the results are quite strong and pervasive. This is particularly true in the debt maturity regressions where corruption, legal system and the size of the banking sector are very strong in all subsamples and sub-periods. Further, the bankruptcy code and domestic savings are also strongly related to debt maturity in all of the subsamples. Deposit insurance, while related to debt maturity in most subsamples, is insignificant in the 19911998 sub-period.

In the leverage regressions the results depend more on subgroups and subperiods. For example, while we find that for the full sample, leverage is higher in countries where the tax gain from leverage is positive, we do not find a significant relation between the tax gain to leverage and debt ratios in the developing economies subsample and the tax effect is insignificant in the 1991-1998 sub-period. Likewise, the effect of both common law and bankruptcy code are insignificant if we restrict the sample to developing economies. However, the relationship between financial leverage and corruption is strong and significant in all subsamples.

Although our emphasis has been on the effect of cross-country differences in institutions on corporate financial choices, our analysis may have implications for the literature on how institutions can promote economic growth. ${ }^{32}$ Specifically, the fact that institutions influence how firms are financed may provide an indirect channel through which a country's institutions affect economic growth. For example, there is reason to

\footnotetext{
${ }^{32}$ Demirguc-Kunt and Maksimovic (1998), Levine and Zervos (1998) and Rajan and Zingales (1998) find that, for a sample of developing and developed countries, the development of stock markets, bond markets and banks facilitate economic growth.
} 
believe that if firms can raise more of their capital with equity and long-term debt, they will be better able to make longer-term investments, which may better promote economic growth. This suggests that an analysis of the relation between investment horizons and institutional structure offers an interesting avenue for future research. 


\section{References:}

Andrew, D.W.K., 1991. Heteroskedasticity and Autocorrelation Consistent Covariance Matrix Estimation. Econometrica 59, 817-858.

Antoniou, A., Guney, Y., Paudyal, K., 2002. Determinants of Corporate Capital Structure: Evidence from European Countries. Unpublished working paper. University of Durham.

Auerbach, A. J., 1979. Share Valuation and Corporate Equity Policy. Journal of Public Economics 11, 291-305.

Barclay, M.J., Smith, C.W., 1995. The Maturity Structure of Corporate Debt. Journal of Finance 50, 609-631.

Beck, T., Demirgüç-Kunt, A., 2009, Financial Institutions and Markets Across Countries and over Time: Data and Analysis. World Bank Policy Research Working Paper No. 4943.

Beck, T., Webb, I., 2003, Economic, Demographic, and Institutional Determinants of Life Insurance Consumption across Countries. The World Bank Economic Review, 17 , 51-88.

Booth, L., Aivazian, V., Demirguc-Kunt, A., Maksimovic, V., 2001. Capital Structures in Developing Countries. Journal of Finance 56, 87-130.

Botero, J., Djankov, S., La Porta, R. Shleifer, A., 2004. The Regulation of Labor. Quarterly Journal of Economics 119, 1339-1382.

Bradley, M., Jarrell, G.A., Kim, H., 1984. On the Existence of an Optimal Capital Structure. Journal of Finance 39, 857-878.

Campbell, J., Hamao, Y., 1995. Changing Corporate Financing Structure and the Main Bank System in Japan. In: Aoki, M., Patrick, H. (Eds.), Japanese Main Bank System. Oxford University Press.

Caprio, G., Laeven, L., Levine, R., 2005. Governance and Bank Valuation. Unpublished working paper. World Bank and University of Minnesota.

Claessens, S., Djankov, S., Klapper, L., 2003. Resolution of Corporate Distress in East Asia. Journal of Empirical Finance 10, 199-216.

Claessens, S., Djankov, S., Mody, A., 2001. Resolution of Financial Distress: An International Perspective on the Design of Bankruptcy Laws, Eds., World Bank Institute Development Studies, Washington, D.C.

Claessens, S., Djankov, S., Nenova, T., 2001. Corporate Risk around the World. Unpublished working paper. World Bank, CEPR, and Harvard University. 
Claessens, S., Klapper, L., 2005. Bankruptcy around the World: Explanations of Its Relative Use. American Law and Economics Review 7, 253-283.

Davydenko, S, Franks, J., 2008. Do Bankruptcy Codes Matter? A Study of Defaults in France, Germany and the U.K. Journal of Finance 63, 565-608.

Degryse, H., Ongena, S., 2005. Distance, Lending Relationship and Competition. Journal of Finance 55, 231-266.

De Jong, A., Rezaul Kabir, R., Nguyen, T., 2008. Capital structure around the world: The roles of firm- and country-specific determinants, Journal of Banking and Finance 32, 1954-1969.

Demirguc-Kunt, A., Maksimovic, V., 1996. Stock Market Development and Firm Financing Choices. Word Bank Economic Review 10, 341-369.

Demirguc-Kunt, A., Maksimovic, V., 1998. Law, Finance and Firm Growth. Journal of Finance 53, 2107-2137.

Demirguc-Kunt, A., Maksimovic, V., 1999. Institutions, Financial Markets, and Firm Debt Maturity. Journal of Financial Economics 54, 295-336.

Demirguc-Kunt, A., Maksimovic, V., 2001. Firms as Financial Intermediaries: Evidence from Trade Credit Data. Unpublished working paper. World Bank and the University of Maryland.

Demirguc-Kunt, A., Karacaovali, B., Laeven, L., 2005. Deposit insurance around the world : a comprehensive database. Unpublished working paper. World Bank.

Diamond, D., 1993. Seniority and Maturity of Debt Contracts. Journal of Financial Economics 33, 341-368.

Djankov, S., La Porta, R., Lopez-de-Silanes, F., Shleifer, A., 2002. The Regulation of Entry. Quarterly Journal of Economics 117, 1-37.

Djankov, S., La Porta, R., Lopez-de-Silanes, F., Shleifer, A., 2003. Courts. Quarterly Journal of Economics 118, 453-517.

Djankov, S., Hart, O., McLiesh, C., Shleifer, A., 2008. Debt Enforcement around the World. Journal of Political Economy, 116, 1105-1149.

Djankov, S., McLiesh, C., Shleifer, A., 2007. Private credit in 129 countries, Journal of Financial Economics 84, 299-329.

Fama, E. F., MacBeth, J.D., 1973. Risk, return, and equilibrium: Empirical tests. Journal of Political Economy 81, 607-636. 
Fisman, R., 2001. Estimating the Value of Political Connections. American Economic Review 91, 1095-1102.

Fisman, R. Love, I, 2003. Trade Credit, Financial Intermediary Development and Industry Growth. Journal of Finance 58, 353-374.

Flannery, M., 1986. Asymmetric Information and Risky Debt Maturity Choice. Journal of Finance 41, pp. 19-37.

Gatward, P. Sharpe, I., 1996. Capital Structure Dynamics with Interrelated Adjustment: Australian Evidence. Australian Journal of Management 21, 89-112.

Giannetti, M., 2003. Do Better Institutions Mitigate Agency Problems? Evidence from Corporate Finance Choices. Journal of Financial and Quantitative Analysis 38, 185-212.

Graham, J.R., 1995. Debt and the Marginal Tax Rate. Journal of Financial Economics 41, 41-73.

Graham, J.R., 2003. Taxes and Corporate Finance: A Review. Review of Financial Studies 16, 1075-1129.

Guedes, J., Opler, T., 1996. The Determinants of the Maturity of Corporate Debt Issues. Journal of Finance 51, 1809-1833.

Himmelberg, C., Hubbard, R.G., Palia, D., 1999. Understanding the Determinants of Managerial Ownership and the Link Between Ownership and Performance. Journal of Financial Economics 53, 353-384.

La Porta, R., Lopez-de-Silanes, F., Shleifer, A., Vishny, R., 1997. Legal Determinants of External Finance. Journal of Finance 52, 1131-1150.

La Porta, R., Lopez-de-Silanes, F., Shleifer, A., Vishny, R., 1998. Law and Finance. Journal of Political Economy 106, 1113-1155.

La Porta, R., Lopez-de-Silanes, F., Shleifer, A., Vishny, R., 1999. The Quality of Government. Journal of Law, Economics and Organization 15, 222-279.

La Porta, R., Lopez-De-Silanes, F., Shleifer, A., 1999. Corporate ownership around the world. Journal of Finance 54, 471-518.

La Porta, R., Lopez-de-Silanes, F., Shleifer, A., Vishny, R., 2000. Agency Problems and Dividend Policies around the World, Journal of Finance 55, 1-33.

La Porta, R., Lopez-de-Silanes, F., Shleifer, A., Vishny, R., 2002. Government Ownership of Banks. Journal of Finance 57, 265-301.

La Porta, R., Lopez-de-Silanes, F., Shleifer, A., Vishny, R., 2002. Investor Protection and Corporate Valuation. Journal of Finance 57, 1147-1170. 
Levine, R., Zervos, S., 1998. Stock Markets, Banks and Economic Growth. American Economic Review 88, 537-558.

MacKay, P., Phillips, G.M., 2005. How does industry affect firm financial structure? Review of Financial Studies 18, 2005, 1433-1466.

Miguel, A., Pindado, J., 2001. Determinants of capital structure: new evidence from Spanish panel data. Journal of Corporate Finance 7, 77-99.

Miller, M.H., 1977. Debt and Taxes. Journal of Finance, 32, 261-275.

Modigliani, F., Miller, M.H., 1958. The Cost of Capital, Corporate Finance, and the Theory of Investment. American Economic Review 48, 261-297.

Modigliani, F., Miller, M.H., 1963. Corporate Income Taxes and the Cost of Capital: A Correction. American Economic Review 53, 433-443.

Myers, S., 2001. Capital Structure. Journal of Economic Perspective 15, 81-102.

Myers, S., Majluf, N., 1984. Corporate Financing and Investment Decisions When Firms Have Information That Investors Do Not Have. Journal of Financial Economics 13, 187221.

Ozkan, A., 2000. An empirical analysis of corporate debt maturity structure. European Financial Management 6, 197-212.

Ozkan, A., 2001. Determinants of Capital Structure and Adjustment to Long Run Targets: Evidence from UK Company Panel Data. Journal of Business Finance and Accounting 28, 175-198.

Perotti, E., Spier, K., 1993. Capital Structure as a Bargaining Tool: The Role of Leverage in Contract Renegotiation. American Economic Review 83, 1131-1141.

Petersen, M.A., 2008. Estimating Standard Errors in Finance Panel Data Sets: Comparing Approaches. Review of Financial Studies 22, 435-480.

Petersen, M., Rajan, R., 1994. The Benefits of Lending Relationship, Evidence from Small Business Data. Journal of Finance 49, 3-37.

Rajan, R., Zingales, L., 1995. What Do We Know about Capital Structure? Some Evidence from International Data. Journal of Finance 50, 1421-1460.

Rajan R., Zingales, L., 1998. Financial Development and Growth. American Economic Review 88, 559-586.

Sapienza, P., 2004. The Effect of Government Ownership on Bank Lending. Journal of Financial Economics 72, 357-384. 
Schmukler, S., Vesperoni, E., 2001. Globalization and Firms' Financing Choices: Evidence from Emerging Economies. Unpublished working paper. World Bank and International Monetary Fund.

Shleifer, A., Vishny, R., 1998. The Grabbing Hand: Government Pathologies and their Cures. Cambridge, MA: Harvard University Press.

Smith, C.W., Warner, J.B., 1979. On Financial Contracting: An Analysis of Bond Covenants. Journal of Financial Economics 7, 117-161.

Stohs, M., Mauer, D., 1996. The Determinants of Corporate Debt Maturity Structure. Journal of Business 69, 279-312.

Titman, S., Wessels, R., 1988. The Determinants of Capital Structure Choice. Journal of Finance 43, 1-19.

Titman, S., 2002. The Modigliani and Miller Theorem and Market Efficiency. Financial Management 31, 101-115.

Treisman, D., 2000. The Causes of Corruption: A Cross National Study. Journal of Public Economics 76, 399-457. 


\section{Figure 1}

\section{Median leverage ratio of sample firms (1991-2006)}

This figure plots the median leverage ratio across 39 different countries. The leverage ratio is measured as total debt over the market value of the firm. Total debt is defined to be the book value of current and long-term interest bearing debt. Market value of the firm is defined to be the market value of common equity plus book value of preferred stock plus total debt.

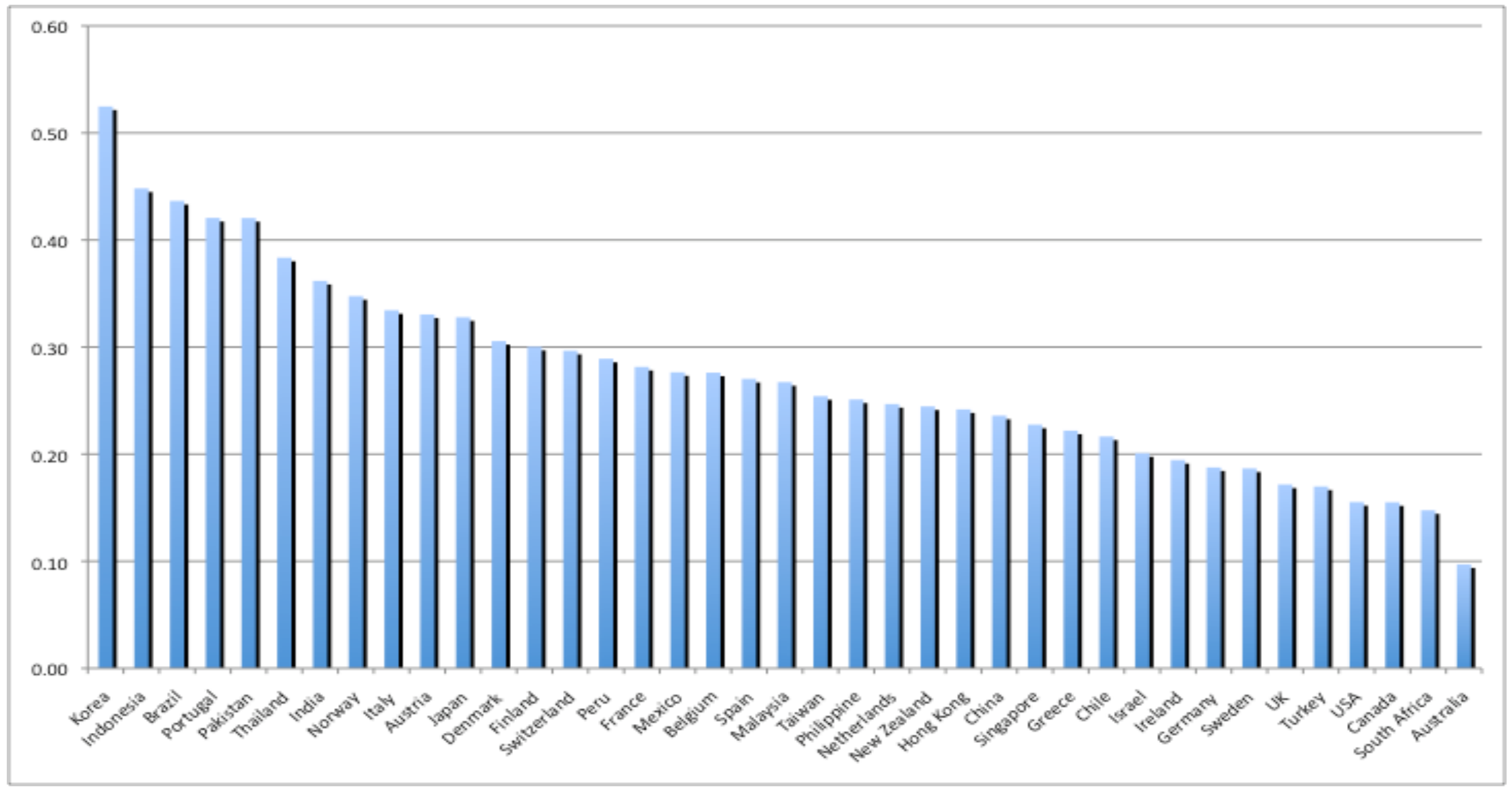


Figure 2

Median long-term debt ratio of sample firms (1991-2006)

This figure plots the median debt maturity ratio across 39 different countries. The debt maturity ratio is measured as long-term interest bearing debt over total debt. Total debt is defined to be the book value of current and long-term interest bearing debt.

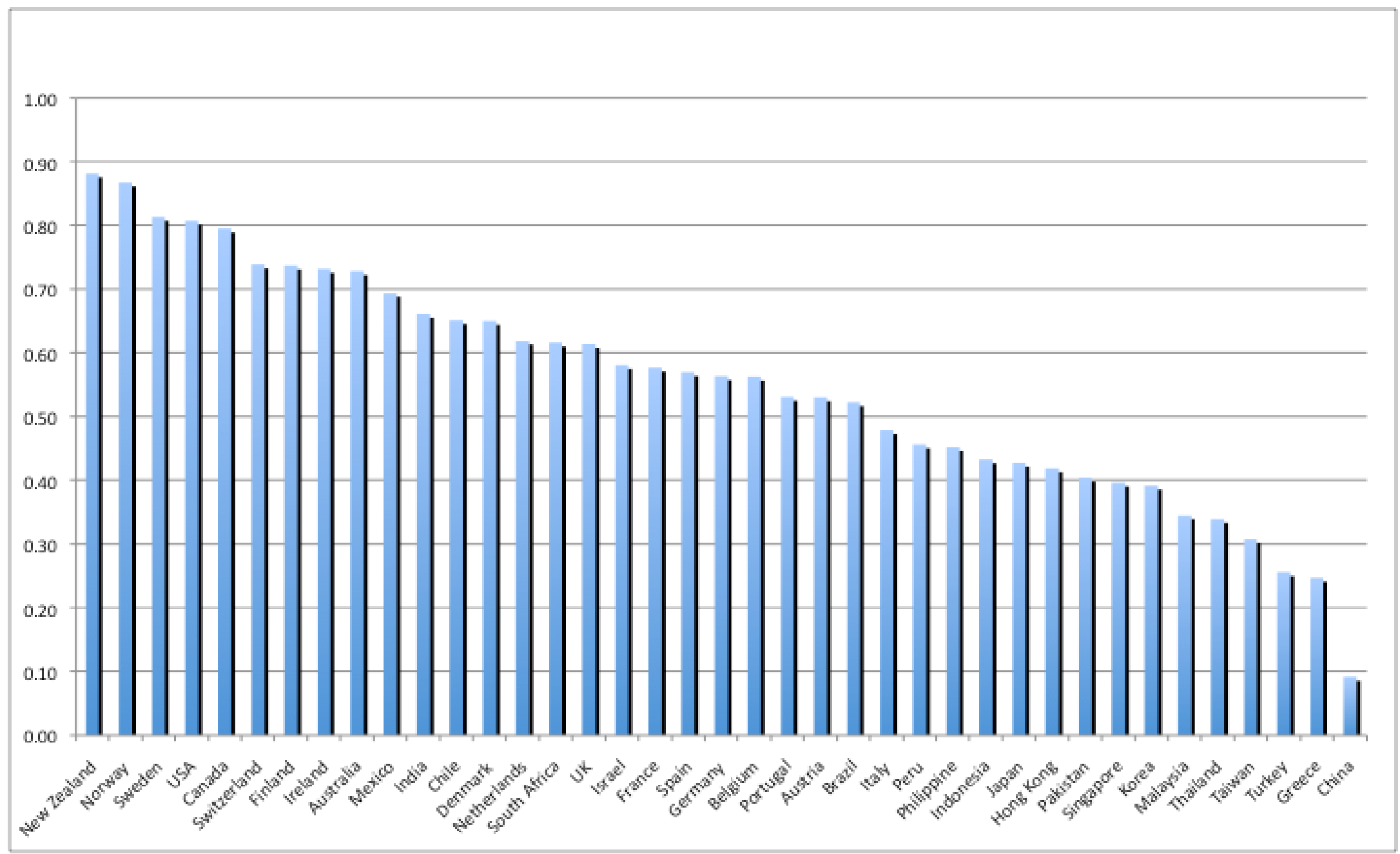




\section{Table 1}

\section{The sample}

The table provides a description of the sample. The number of years that data is available for each country. The mean number of firms per year for each country. The median value of the proportion of firms represented in the sample for each country, by number of firms and market capitalization.

\begin{tabular}{|c|c|c|c|c|c|}
\hline \multirow[b]{2}{*}{ Country } & \multirow[b]{2}{*}{$\begin{array}{l}\text { Number of } \\
\text { years of data } \\
\text { used }\end{array}$} & \multirow[b]{2}{*}{$\begin{array}{l}\text { Number of } \\
\text { firms in the } \\
\text { sample }\end{array}$} & \multirow[b]{2}{*}{ Firm-years } & \multicolumn{2}{|c|}{ Time series median value } \\
\hline & & & & $\begin{array}{l}\text { Number of firms in the } \\
\text { sample/Total number of } \\
\text { listed firms }\end{array}$ & $\begin{array}{c}\text { Market capitalization of firms in } \\
\text { the sample/Stock market } \\
\text { capitalization }\end{array}$ \\
\hline Australia & 16 & 1554 & 8308 & 0.50 & 0.79 \\
\hline Austria & 16 & 139 & 1144 & 0.75 & 0.61 \\
\hline Belgium & 16 & 169 & 1485 & 0.59 & 0.49 \\
\hline Brazil & 16 & 351 & 2591 & 0.46 & 0.87 \\
\hline Canada & 16 & 1865 & 10988 & 0.34 & 0.79 \\
\hline Switzerland & 16 & 274 & 2656 & 0.72 & 0.77 \\
\hline Chile & 16 & 158 & 1424 & 0.41 & 0.58 \\
\hline China & 13 & 1530 & 6827 & 0.57 & 0.44 \\
\hline Germany & 16 & 1011 & 9209 & 0.90 & 0.69 \\
\hline Denmark & 16 & 208 & 2123 & 0.64 & 0.88 \\
\hline Spain & 16 & 223 & 2315 & 0.17 & 0.48 \\
\hline Finland & 16 & 175 & 1684 & 0.95 & 0.83 \\
\hline France & 16 & 1205 & 9664 & 0.87 & 0.73 \\
\hline UK & 16 & 2861 & 21785 & 0.67 & 0.62 \\
\hline Greece & 16 & 321 & 2511 & 0.64 & 0.53 \\
\hline Hong Kong & 16 & 939 & 7108 & 0.62 & 0.85 \\
\hline Indonesia & 16 & 295 & 2573 & 0.62 & 0.70 \\
\hline India & 15 & 637 & 4388 & 0.07 & 0.39 \\
\hline Ireland & 16 & 109 & 880 & 0.89 & 0.49 \\
\hline Israel & 13 & 181 & 949 & 0.15 & 0.36 \\
\hline Italy & 16 & 343 & 2810 & 0.73 & 0.55 \\
\hline Japan & 16 & 4088 & 42611 & 0.97 & 0.86 \\
\hline Korea & 16 & 970 & 6741 & 0.40 & 0.72 \\
\hline Mexico & 16 & 151 & 1230 & 0.51 & 0.92 \\
\hline Malaysia & 16 & 1011 & 7586 & 0.71 & 0.86 \\
\hline Netherlands & 16 & 280 & 2612 & 0.73 & 0.88 \\
\hline Norway & 16 & 266 & 1826 & 0.77 & 0.92 \\
\hline New Zealand & 16 & 134 & 954 & 0.49 & 0.94 \\
\hline Pakistan & 16 & 114 & 1061 & 0.11 & 0.42 \\
\hline Peru & 14 & 74 & 491 & 0.20 & 0.55 \\
\hline Philippine & 16 & 188 & 1648 & 0.53 & 0.81 \\
\hline Portugal & 16 & 110 & 867 & 0.67 & 0.61 \\
\hline Singapore & 16 & 628 & 4111 & 0.76 & 0.82 \\
\hline Sweden & 16 & 447 & 3394 & 0.86 & 0.91 \\
\hline Thailand & 16 & 481 & 3457 & 0.60 & 0.73 \\
\hline Turkey & 15 & 201 & 1422 & 0.40 & 0.74 \\
\hline Taiwan & 16 & 1399 & 7051 & 0.68 & 0.74 \\
\hline USA & 16 & 11119 & 77909 & 0.81 & 0.81 \\
\hline South Africa & 16 & 558 & 3699 & 0.53 & 0.78 \\
\hline
\end{tabular}


Table 2

\section{Summary statistics}

The table provides the mean, standard deviation, median, minimum and maximum values of each variable. Leverage ratio is the ratio of total debt to market value of the firm. Total debt is defined to be the book value of short-term and long-term interest bearing debt. Market value of the firm is defined to be the market value of common equity plus book value of preferred stock plus total debt. Maturity structure ratio is the ratio of long-term debt to total debt. Tangible assets/total assets is the ratio of fixed assets to total assets, operating risk is measured as the absolute value of the annual change in ROA, ROA is the ratio of net income to total assets, firm size is measured as the natural logarithm of total assets and the market-to-book ratio is the ratio of market value of equity plus book value of total debt over total assets. Country characteristic variables are Development economy is a dummy variable equal to one when the country is classified as developed according to the World Bank classification based on countries' gross national income levels. Inflation rate is the annual rate of change in a country's CPI. Inflation rate volatility is the standard deviation of inflation rates from period t- 4 to t. Corruption index is an index ranging from 0 to 10 , with larger value indicating more severe corruption. Common law is a dummy variable equal to one when a country adopts the common law system. Bankruptcy code is a dummy variable equal to one if an insolvent firm is most likely to undergo a reorganization proceeding. Tax is an estimate of the miller tax ratio calculated using statutory tax rates. Deposits is the ratio of a country's bank deposits to GDP. Deposit insurance is a dummy variable equal to one if bank deposits are insured by government. Domestic savings is the ratio of gross domestic saving to GDP. Insurance penetration is the value of a country's total insurance premiums to GDP. Pension fund regulation index is an index of relative restrictions on debt and equity holdings of pension funds ranging from 1 to 4 . Defined benefit pensions is the value of the country's defined benefit pension fund assets to GDP. Defined contribution pensions is the value of the country's defined contribution pension fund assets to GDP. Government bonds is the ratio of the value of domestically denominated government bonds to GDP.

\begin{tabular}{lcccccc}
\hline Variables & $\mathrm{N}$ & Mean & Std Dev & Median & Minimum & Maximum \\
\hline Leverage ratio & 264236 & 0.29 & 0.26 & 0.22 & 0.00 & 1.00 \\
Maturity structure ratio & 235874 & 0.53 & 0.34 & 0.57 & 0.00 & 1.00 \\
Tangible assets/total assets & 264236 & 0.33 & 0.24 & 0.29 & 0.00 & 0.97 \\
ROA & 264236 & -0.13 & 0.98 & 0.02 & -12.25 & 0.43 \\
Log total assets & 264236 & 19.76 & 4.21 & 19.82 & -10.93 & 31.94 \\
Market-to-book ratio & 264236 & 2.50 & 6.87 & 1.51 & -35.15 & 63.26 \\
Developed economy & 624 & 0.86 & 0.35 & 1.00 & 0.00 & 1.00 \\
Inflation rate & 624 & 0.03 & 0.05 & 0.02 & -0.04 & 0.54 \\
Inflation rate volatility & 624 & 0.02 & 0.39 & 0.01 & 0.00 & 32.88 \\
Corruption index & 624 & 3.01 & 1.74 & 2.50 & 0.00 & 9.43 \\
Common law & 624 & 0.59 & 0.49 & 1.00 & 0.00 & 1.00 \\
Bankruptcy code & 624 & 0.68 & 0.47 & 1.00 & 0.00 & 1.00 \\
Tax & 624 & 0.23 & 0.15 & 0.28 & -0.30 & 0.51 \\
Deposits & 624 & 0.93 & 0.57 & 0.67 & 0.13 & 2.46 \\
Deposit insurance & 624 & 0.87 & 0.34 & 1.00 & 0.00 & 1.00 \\
Domestic savings & 624 & 0.23 & 0.09 & 0.22 & 0.09 & 0.52 \\
Insurance penetration & 624 & 0.08 & 0.03 & 0.09 & 0.01 & 0.18 \\
Pension fund regulation index & 457 & 3.18 & 1.06 & 4.00 & 1.00 & 4.00 \\
Defined benefit pensions & 72 & 37.55 & 19.07 & 48.10 & .08 & 71.33 \\
Defined contribution pensions & 72 & 24.72 & 18.41 & 29.86 & .03 & 119.97 \\
Government bonds & 624 & 0.36 & 0.25 & 0.30 & 0.00 & 1.19 \\
\hline
\end{tabular}


Table 3

\section{Correlation matrix}

The table provides correlation matrix for our sample. Pearson correlation coefficients for all independent variables, leverage and debt maturity, together with each pairing of independent variables are presented. Variables are as defined in Table 2.

\begin{tabular}{|c|c|c|c|c|c|c|c|c|c|c|c|}
\hline & & {$[1]$} & {$[2]$} & [3] & [4] & [5] & [6] & [7] & [8] & [9] & [10] \\
\hline Leverage ratio & {$[1]$} & 1.000 & & & & & & & & & \\
\hline Maturity structure ratio & {$[2]$} & 0.062 & 1.000 & & & & & & & & \\
\hline $\mathrm{ROA}$ & {$[3]$} & 0.033 & 0.096 & 1.000 & & & & & & & \\
\hline Market-to-book ratio & {$[5]$} & -0.136 & 0.012 & 0.082 & -0.042 & 1.000 & & & & & \\
\hline Developed economy & {$[6]$} & -0.075 & 0.139 & -0.058 & -0.122 & 0.025 & 1.000 & & & & \\
\hline Inflation rate & {$[7]$} & 0.021 & 0.001 & 0.013 & -0.060 & -0.001 & -0.374 & 1.000 & & & \\
\hline Inflation rate volatility & {$[8]$} & 0.014 & -0.011 & 0.005 & -0.028 & -0.006 & -0.091 & 0.340 & 1.000 & & \\
\hline Corruption index & {$[9]$} & 0.165 & -0.210 & 0.066 & 0.313 & -0.041 & -0.757 & 0.328 & 0.073 & 1.000 & \\
\hline Common law & [10] & -0.157 & 0.173 & -0.112 & -0.414 & 0.035 & 0.054 & -0.013 & -0.041 & -0.293 & 1.000 \\
\hline Bankruptcy code & [11] & 0.071 & 0.095 & -0.060 & 0.163 & -0.003 & 0.283 & -0.045 & -0.039 & 0.089 & -0.072 \\
\hline Tax & [12] & 0.061 & 0.036 & 0.014 & 0.213 & 0.014 & -0.041 & -0.118 & 0.019 & 0.080 & 0.014 \\
\hline Deposits & [13] & 0.070 & -0.135 & 0.045 & 0.337 & -0.027 & 0.234 & -0.325 & -0.044 & -0.147 & -0.315 \\
\hline Deposit insurance & [14] & 0.037 & 0.107 & -0.027 & 0.014 & 0.009 & 0.298 & -0.042 & -0.067 & -0.130 & -0.126 \\
\hline Domestic savings & {$[15]$} & 0.109 & -0.229 & 0.114 & 0.337 & -0.039 & -0.401 & -0.117 & -0.003 & 0.323 & -0.349 \\
\hline Insurance penetration & [16] & 0.003 & -0.066 & 0.021 & 0.183 & -0.010 & 0.317 & -0.257 & -0.046 & -0.206 & -0.066 \\
\hline Pension fund regulation index & [17] & -0.034 & 0.071 & -0.068 & 0.000 & 0.029 & 0.431 & -0.160 & -0.080 & -0.192 & 0.159 \\
\hline Defined contribution pensions & [19] & -0.088 & -0.089 & -0.082 & -0.343 & 0.046 & 0.075 & 0.272 & -0.108 & -0.295 & 0.395 \\
\hline Government bonds & [20] & 0.061 & -0.107 & 0.072 & 0.272 & -0.025 & 0.158 & -0.195 & -0.043 & 0.015 & -0.467 \\
\hline
\end{tabular}


Table 3 (continued)

\section{Correlation matrix}

The table provides correlation matrix for our sample. Pearson correlation coefficients for all independent variables, leverage and debt maturity, together with each pairing of independent variables are presented. Variables are as defined in Table 2.

\begin{tabular}{|c|c|c|c|c|c|c|c|c|c|c|}
\hline & & [11] & {$[12]$} & {$[13]$} & [14] & {$[15]$} & [16] & [17] & [18] & [19] \\
\hline Bankruptcy code & {$[11]$} & 1.000 & & & & & & & & \\
\hline Tax & [12] & 0.344 & 1.000 & & & & & & & \\
\hline Deposits & [13] & 0.088 & 0.297 & 1.000 & & & & & & \\
\hline Deposit insurance & [14] & 0.521 & 0.117 & 0.053 & 1.000 & & & & & \\
\hline Domestic savings & {$[15]$} & -0.256 & 0.113 & 0.296 & -0.406 & 1.000 & & & & \\
\hline Insurance penetration & {$[16]$} & 0.061 & 0.143 & 0.465 & 0.102 & 0.013 & 1.000 & & & \\
\hline Pension fund regulation index & [17] & 0.549 & 0.441 & 0.269 & 0.337 & -0.396 & 0.033 & 1.000 & & \\
\hline Defined benefit pensions & [18] & 0.391 & 0.209 & -0.622 & 0.323 & -0.686 & -0.176 & 0.225 & 1.000 & \\
\hline Defined contribution pensions & [19] & 0.081 & 0.060 & -0.555 & 0.141 & -0.430 & 0.128 & -0.039 & 0.730 & 1.000 \\
\hline Government bonds & [20] & 0.160 & 0.136 & 0.532 & 0.234 & 0.011 & 0.281 & 0.266 & -0.591 & -0.603 \\
\hline
\end{tabular}




\section{Table 4}

\section{Leverage, firm and country level determinants}

This table presents regressions of leverage on both firm and country level variables, as defined in Table 2 . All regressions include dummy variables for industry (two digit SIC codes). The sample is divided between developed and developing economies as defined by the developed economy indicator variable, a sample of OECD member countries for which pension fund bond/equity holding restriction information is available and a select sample of OECD countries for which pension fund asset information is available. The sample is split into two sub-samples, 1991-1998 and 1999-2006. This table also reports the adjusted R-squared and number of firm-year observations. Standard errors are robust to clustering within country over time. T-statistics are given in parentheses.

\begin{tabular}{|c|c|c|c|c|c|c|c|}
\hline $\begin{array}{l}\text { Sample } \\
\text { Independent variable }\end{array}$ & $\begin{array}{c}\text { Full } \\
\text { Sample } \\
\text { (1) }\end{array}$ & $\begin{array}{c}\text { Developed } \\
\text { Economies } \\
\text { (2) }\end{array}$ & $\begin{array}{c}\text { Developing } \\
\text { Economy } \\
(3)\end{array}$ & $\begin{array}{c}1991-1998 \\
(4)\end{array}$ & $\begin{array}{c}1999-2006 \\
(5)\end{array}$ & \multicolumn{2}{|c|}{ OECD Select OECD } \\
\hline \multicolumn{8}{|l|}{ Firm Factors: } \\
\hline Tangible assets/total assets & $\begin{array}{c}0.2178 \\
(28.68)^{* * *}\end{array}$ & $\begin{array}{c}0.2274 \\
(25.93)^{* * *}\end{array}$ & $\begin{array}{c}0.1171 \\
(11.39)^{* * *}\end{array}$ & $\begin{array}{c}0.1738 \\
(19.32)^{* * *}\end{array}$ & $\begin{array}{c}0.2359 \\
(25.76)^{* * *}\end{array}$ & $\begin{array}{c}0.2176 \\
(25.65)^{* * *}\end{array}$ & $\begin{array}{c}0.2221 \\
(15.28)^{* * *}\end{array}$ \\
\hline ROA & $\begin{array}{c}-0.0201 \\
(-3.77)^{* * *}\end{array}$ & $\begin{array}{c}-0.0144 \\
(-3.04) * * *\end{array}$ & $\begin{array}{c}-0.2268 \\
(-8.44)^{* * * *}\end{array}$ & $\begin{array}{c}-0.1737 \\
(-3.63) * * *\end{array}$ & $\begin{array}{c}-0.0117 \\
(-2.41)^{* * *}\end{array}$ & $\begin{array}{c}-0.0159 \\
(-3.12)^{* * *}\end{array}$ & $\begin{array}{c}-0.0074 \\
(-1.76) * * *\end{array}$ \\
\hline Log total assets & $\begin{array}{c}0.0065 \\
(7.97)^{* * *}\end{array}$ & $\begin{array}{c}0.0057 \\
(7.09)^{* * *}\end{array}$ & $\begin{array}{c}0.0109 \\
(7.82)^{* * *}\end{array}$ & $\begin{array}{c}0.0070 \\
(4.51)^{* * *}\end{array}$ & $\begin{array}{c}0.0060 \\
(7.11)^{* * *}\end{array}$ & $\begin{array}{c}0.0056 \\
(7.05) * * *\end{array}$ & $\begin{array}{c}0.0029 \\
(5.20) * * *\end{array}$ \\
\hline Market-to-book ratio & $\begin{array}{c}-0.0081 \\
(-18.04)^{* * *}\end{array}$ & $\begin{array}{c}-0.0075 \\
(-16.98)^{* * *}\end{array}$ & $\begin{array}{c}-0.0096 \\
(-10.45)^{* * *}\end{array}$ & $\begin{array}{c}-0.0110 \\
(-12.69)^{* * *}\end{array}$ & $\begin{array}{c}-0.0071 \\
(-18.62)^{* * *}\end{array}$ & $\begin{array}{c}-0.0076 \\
(-16.97)^{* * *}\end{array}$ & $\begin{array}{c}-0.0068 \\
(-13.89)^{* * *}\end{array}$ \\
\hline \multicolumn{8}{|l|}{ Country factors: } \\
\hline Developed economy & $\begin{array}{c}0.1006 \\
(6.20)^{* * *}\end{array}$ & & & $\begin{array}{c}0.1075 \\
(4.42)^{* * *}\end{array}$ & $\begin{array}{c}0.1071 \\
(5.80)^{* * *}\end{array}$ & $\begin{array}{c}0.1069 \\
(4.53) * * *\end{array}$ & $\begin{array}{c}0.1361 \\
(2.28)^{* * *}\end{array}$ \\
\hline Inflation rate & -0.0363 & -0.2222 & 0.0917 & -0.0674 & 0.0650 & -0.0958 & -0.6182 \\
\hline & $(-0.66)$ & $(-0.92)$ & $(1.75)^{*}$ & $(-0.58)$ & $(1.17)$ & $(-1.35)$ & $(-1.47)$ \\
\hline Inflation rate volatility & $\begin{array}{c}0.0043 \\
(0.74)\end{array}$ & $\begin{array}{c}1.1850 \\
(2.04)^{* *}\end{array}$ & $\begin{array}{c}0.0033 \\
(0.57)\end{array}$ & $\begin{array}{c}0.0029 \\
(0.41)\end{array}$ & $\begin{array}{c}0.3570 \\
(2.29)^{* * *}\end{array}$ & $\begin{array}{c}0.0093 \\
(1.51)\end{array}$ & $\begin{array}{c}1.2617 \\
(2.84)^{* * *}\end{array}$ \\
\hline Corruption index & $\begin{array}{c}0.0222 \\
(6.89)^{* * *}\end{array}$ & $\begin{array}{c}0.0232 \\
(6.28)^{* * *}\end{array}$ & $\begin{array}{c}0.0261 \\
(5.12)^{* * *}\end{array}$ & $\begin{array}{c}0.0255 \\
(5.69)^{* * *}\end{array}$ & $\begin{array}{c}0.0183 \\
(4.71)^{* * *}\end{array}$ & $\begin{array}{c}0.0240 \\
(6.60)^{* * *}\end{array}$ & $\begin{array}{c}0.0092 \\
(1.98)^{* *}\end{array}$ \\
\hline Common law & $\begin{array}{c}-0.0330 \\
(-3.91)^{* * *}\end{array}$ & $\begin{array}{c}-0.0477 \\
(-5.43) * * *\end{array}$ & $\begin{array}{c}0.0430 \\
(0.98)\end{array}$ & $\begin{array}{c}-0.0537 \\
(-4.46) * * *\end{array}$ & $\begin{array}{c}-0.0266 \\
(-2.61) * * *\end{array}$ & $\begin{array}{c}-0.0410 \\
(-4.52) * * *\end{array}$ & $\begin{array}{c}-0.2615 \\
(-7.23) * * *\end{array}$ \\
\hline Bankruptcy code & $\begin{array}{c}0.0113 \\
(3.51)^{* * *}\end{array}$ & $\begin{array}{c}0.0097 \\
(2.87)^{* * *}\end{array}$ & $\begin{array}{c}-0.0136 \\
(-1.51)\end{array}$ & $\begin{array}{c}0.0197 \\
(4.16)^{* * *}\end{array}$ & $\begin{array}{c}0.0068 \\
(2.13)^{* *}\end{array}$ & $\begin{array}{c}0.0123 \\
(2.66) * * *\end{array}$ & $\begin{array}{c}0.0378 \\
(2.32)^{* *}\end{array}$ \\
\hline Tax & $\begin{array}{c}0.0654 \\
(2.22)^{* *}\end{array}$ & $\begin{array}{c}0.1005 \\
(3.05) * * *\end{array}$ & $\begin{array}{c}-0.0778 \\
(-1.01)\end{array}$ & $\begin{array}{c}-0.0268 \\
(-0.78)\end{array}$ & $\begin{array}{c}0.1790 \\
(5.03)^{* * *}\end{array}$ & $\begin{array}{c}0.1176 \\
(3.55)^{* * *}\end{array}$ & $\begin{array}{l}0.1295 \\
(1.70)^{*}\end{array}$ \\
\hline Deposits/GDP & $\begin{array}{l}0.0004 \\
(0.05)\end{array}$ & $\begin{array}{c}-0.0198 \\
(-2.25)^{* *}\end{array}$ & $\begin{array}{c}-0.0057 \\
(-0.08)\end{array}$ & $\begin{array}{c}-0.0178 \\
(-1.13)\end{array}$ & $\begin{array}{c}0.0060 \\
(0.72)\end{array}$ & $\begin{array}{c}-0.0060 \\
(-0.55)\end{array}$ & $\begin{array}{c}-0.0298 \\
(-1.48)\end{array}$ \\
\hline Deposit insurance & $\begin{array}{c}0.0069 \\
(2.36)^{* * *}\end{array}$ & $\begin{array}{c}-0.0066 \\
(-2.15)^{* *}\end{array}$ & $\begin{array}{c}0.0400 \\
(4.81)^{* * *}\end{array}$ & $\begin{array}{c}-0.0016 \\
(-0.29)\end{array}$ & $\begin{array}{c}0.0116 \\
(3.31)^{* * *}\end{array}$ & $\begin{array}{c}0.0082 \\
(1.85)^{* * *}\end{array}$ & $\begin{array}{c}-0.0067 \\
(-0.59)\end{array}$ \\
\hline Domestic savings & $\begin{array}{l}0.0044 \\
(1.25)\end{array}$ & $\begin{array}{l}0.0008 \\
(0.19)\end{array}$ & $\begin{array}{l}-0.0102 \\
(-1.34)\end{array}$ & $\begin{array}{c}0.0178 \\
(2.85)^{* * *}\end{array}$ & $\begin{array}{c}0.0007 \\
(0.22)\end{array}$ & $\begin{array}{c}0.0002 \\
(0.04)\end{array}$ & $\begin{array}{c}-0.0181 \\
(-2.23)^{* * *}\end{array}$ \\
\hline Insurance penetration & $\begin{array}{c}-0.0007 \\
(-0.01)\end{array}$ & $\begin{array}{l}0.0930 \\
(0.71)\end{array}$ & $\begin{array}{c}0.1373 \\
(0.42)\end{array}$ & $\begin{array}{c}0.2201 \\
(1.14)\end{array}$ & $\begin{array}{c}-0.0645 \\
(-0.49)\end{array}$ & $\begin{array}{c}0.0007 \\
(0.01)\end{array}$ & $\begin{array}{c}1.6296 \\
(2.13)^{* *}\end{array}$ \\
\hline Government bonds & $\begin{array}{c}-0.0350 \\
(-1.60)\end{array}$ & $\begin{array}{c}-0.0238 \\
(-1.07)\end{array}$ & $\begin{array}{c}-0.1942 \\
(-3.37)^{* * *}\end{array}$ & $\begin{array}{c}-0.1212 \\
(-4.19) * * *\end{array}$ & $\begin{array}{c}-0.0345 \\
(-1.18)\end{array}$ & $\begin{array}{c}-0.0389 \\
(-1.72)^{* * *}\end{array}$ & $\begin{array}{c}-0.2254 \\
(-5.37) * * *\end{array}$ \\
\hline Pension fund regulation index & & & & & & $\begin{array}{c}-0.0068 \\
(-1.78) * * *\end{array}$ & \\
\hline Defined benefit pensions & & & & & & & $\begin{array}{c}0.0032 \\
(3.35)^{* * *}\end{array}$ \\
\hline Defined contribution pensions & & & & & & & $\begin{array}{l}-0.0024 \\
(-2.20)^{* *}\end{array}$ \\
\hline Number of observations & 250668 & 218847 & 31821 & 87515 & 163153 & 232656 & 112722 \\
\hline Adjusted R-square & 0.1798 & 0.1959 & 0.1689 & 0.1958 & 0.1932 & 0.1862 & 0.1891 \\
\hline
\end{tabular}
$* * *$, and $* * *$, significant at the 10,5 and 1 percent level, respectively. 


\section{Table 5}

\section{Debt maturity structure, firm and country level determinants}

This table presents regressions of debt maturity on both firm and country level variables, as defined in Table 2 . All regressions include dummy variables for industry (two digit SIC codes). The sample is dividend between developed and developing economies as defined by the developed economy indicator variable, a sample of OECD member countries for which pension fund bond/equity holding restriction information is available and a select sample of OECD countries for which pension fund asset information is available. This table also reports the adjusted R-squared and number of firm-year observations. Standard errors are robust to clustering within country over time. T-statistics are given in parentheses.

Dependent variable: Long-term debt/Total debt

\begin{tabular}{|c|c|c|c|c|c|c|}
\hline $\begin{array}{l}\text { Sample } \\
\text { Independent variable }\end{array}$ & $\begin{array}{l}\text { Full Sample } \\
\text { (1) }\end{array}$ & $\begin{array}{l}\text { Developed } \\
\text { Economy } \\
(2)\end{array}$ & $\begin{array}{l}\text { Developing } \\
\text { Economy } \\
\text { (3) }\end{array}$ & $\begin{array}{c}1991-1998 \\
(4)\end{array}$ & $\begin{array}{c}1999-2006 \\
(5)\end{array}$ & $\begin{array}{c}\text { Select } \\
\text { OECD } \\
\text { Sample } \\
(6)\end{array}$ \\
\hline \multicolumn{7}{|l|}{ Firm Factors: } \\
\hline Tangible assets/total assets & $\begin{array}{c}0.2648 \\
(46.94)^{* * *}\end{array}$ & $\begin{array}{c}0.2707 \\
(44.70)^{* * *}\end{array}$ & $\begin{array}{c}0.2990 \\
(23.77)^{* * *}\end{array}$ & $\begin{array}{c}0.2704 \\
(37.8)^{* * *}\end{array}$ & $\begin{array}{c}0.2659 \\
(37.34)^{* * *}\end{array}$ & $\begin{array}{c}0.2699 \\
(39.22)^{* * *}\end{array}$ \\
\hline ROA & $\begin{array}{c}0.0765 \\
(24.22)^{* * *}\end{array}$ & $\begin{array}{c}0.0800 \\
(26.65)^{* * * *}\end{array}$ & $\begin{array}{c}0.0650 \\
(4.30)^{* * *}\end{array}$ & $\begin{array}{c}0.0701 \\
(7.12)^{* * *}\end{array}$ & $\begin{array}{c}0.0733 \\
(22.36)^{* * *}\end{array}$ & $\begin{array}{c}0.0811 \\
(46.43)^{* * *}\end{array}$ \\
\hline Log total assets & $\begin{array}{c}0.0139 \\
(23.32)^{* * *}\end{array}$ & $\begin{array}{c}0.0152 \\
(26.44)^{* * *}\end{array}$ & $\begin{array}{c}0.0157 \\
(12.12)^{* * *}\end{array}$ & $\begin{array}{c}0.0106 \\
(16.58)^{* * *}\end{array}$ & $\begin{array}{c}0.0149 \\
(20.74)^{* * *}\end{array}$ & $\begin{array}{c}0.0168 \\
(24.57)^{* * *}\end{array}$ \\
\hline Market-to-book ratio & $\begin{array}{l}0.0005 \\
(1.61)\end{array}$ & $\begin{array}{l}0.0001 \\
(0.44)\end{array}$ & $\begin{array}{c}0.0034 \\
(3.67)^{* * *}\end{array}$ & $\begin{array}{l}0.0004 \\
(0.83)\end{array}$ & $\begin{array}{l}0.0003 \\
(1.23)\end{array}$ & $\begin{array}{c}-0.0038 \\
(-1.55)\end{array}$ \\
\hline \multicolumn{7}{|l|}{ Country factors: } \\
\hline Developed economy & $\begin{array}{c}0.1422 \\
(8.94)^{* * *}\end{array}$ & & & $\begin{array}{c}0.1434 \\
(5.23)^{* * *}\end{array}$ & $\begin{array}{c}0.1296 \\
(7.12)^{* * *}\end{array}$ & $\begin{array}{l}0.0796 \\
(2.09)^{* *}\end{array}$ \\
\hline Inflation rate & $\begin{array}{l}0.0883 \\
(1.31)\end{array}$ & $\begin{array}{l}0.2335 \\
(0.97)\end{array}$ & $\begin{array}{c}0.1641 \\
(3.17)^{* * *}\end{array}$ & $\begin{array}{c}0.2414 \\
(2.09)^{* *}\end{array}$ & $\begin{array}{l}0.0047 \\
(0.09)\end{array}$ & $\begin{array}{c}0.9699 \\
(2.54)^{* * *}\end{array}$ \\
\hline Inflation rate volatility & $\begin{array}{l}0.0046 \\
(0.70)\end{array}$ & $\begin{array}{c}-3.0938 \\
(-5.00)^{* * *}\end{array}$ & $\begin{array}{l}0.0054 \\
(0.90)\end{array}$ & $\begin{array}{l}0.0002 \\
(0.04)\end{array}$ & $\begin{array}{l}-0.2641 \\
(-1.73)^{*}\end{array}$ & $\begin{array}{c}-1.6375 \\
(-4.65)^{* * *}\end{array}$ \\
\hline Corruption index & $\begin{array}{c}-0.0352 \\
(-11.71)^{* * *}\end{array}$ & $\begin{array}{c}-0.0335 \\
(-9.57)^{* * *}\end{array}$ & $\begin{array}{c}-0.0145 \\
(-4.03)^{* * *}\end{array}$ & $\begin{array}{c}-0.0321 \\
(-8.45)^{* * *}\end{array}$ & $\begin{array}{c}-0.0386 \\
(-9.81)^{* * *}\end{array}$ & $\begin{array}{l}-0.0043 \\
(-1.81)^{*}\end{array}$ \\
\hline Common law & $\begin{array}{c}0.0749 \\
(8.08)^{* * *}\end{array}$ & $\begin{array}{c}0.0742 \\
(7.54)^{* * *}\end{array}$ & $\begin{array}{c}0.1821 \\
(7.55)^{* * *}\end{array}$ & $\begin{array}{c}0.0977 \\
(6.85)^{* * *}\end{array}$ & $\begin{array}{c}0.0736 \\
(7.23)^{* * *}\end{array}$ & $\begin{array}{c}0.1424 \\
(5.12)^{* * *}\end{array}$ \\
\hline Bankruptcy code & $\begin{array}{c}0.0460 \\
(15.68)^{* * *}\end{array}$ & $\begin{array}{c}0.0489 \\
(14.50)^{* * *}\end{array}$ & $\begin{array}{c}0.0096 \\
(2.19)^{* * *}\end{array}$ & $\begin{array}{c}0.0599 \\
(9.90)^{* * *}\end{array}$ & $\begin{array}{c}0.0425 \\
(14.92)^{* * *}\end{array}$ & $\begin{array}{c}0.0258 \\
(2.84)^{* * * *}\end{array}$ \\
\hline Deposits/GDP & $\begin{array}{c}-0.1245 \\
(-16.33)^{* * *}\end{array}$ & $\begin{array}{c}-0.1176 \\
(-13.43)^{* * *}\end{array}$ & $\begin{array}{c}-0.2805 \\
(-5.73)^{* * *}\end{array}$ & $\begin{array}{c}-0.0968 \\
(-7.81)^{* * *}\end{array}$ & $\begin{array}{c}-0.1320 \\
(-15.32)^{* * *}\end{array}$ & $\begin{array}{c}-0.1414 \\
(-8.35)^{* * *}\end{array}$ \\
\hline Deposit insurance & $\begin{array}{c}0.0147 \\
(4.33)^{* * *}\end{array}$ & $\begin{array}{c}0.0147 \\
(3.87)^{* * *}\end{array}$ & $\begin{array}{c}0.0433 \\
(8.98)^{* * *}\end{array}$ & $\begin{array}{c}-0.0089 \\
(-1.61)\end{array}$ & $\begin{array}{c}0.0283 \\
(8.73)^{* * *}\end{array}$ & $\begin{array}{l}0.0110 \\
(1.36)\end{array}$ \\
\hline Domestic savings & $\begin{array}{c}-0.0335 \\
(-11.76)^{* * *}\end{array}$ & $\begin{array}{c}-0.0419 \\
(-12.75)^{* * *}\end{array}$ & $\begin{array}{c}-0.0201 \\
(-4.25)^{* * *}\end{array}$ & $\begin{array}{c}-0.0332 \\
(-6.02)^{* * *}\end{array}$ & $\begin{array}{c}-0.0353 \\
(-11.75)^{* * *}\end{array}$ & $\begin{array}{l}-0.0116 \\
(-1.69)^{*}\end{array}$ \\
\hline Insurance penetration & $\begin{array}{c}0.1272 \\
(1.06)\end{array}$ & $\begin{array}{l}-0.1039 \\
(-0.79)\end{array}$ & $\begin{array}{c}0.6509 \\
(3.40)^{* * *}\end{array}$ & $\begin{array}{c}0.1880 \\
(0.88)\end{array}$ & $\begin{array}{l}0.1398 \\
(0.91)\end{array}$ & $\begin{array}{c}0.6295 \\
(1.09)\end{array}$ \\
\hline Government bonds & $\begin{array}{c}-0.0814 \\
(-4.74)^{* * *}\end{array}$ & $\begin{array}{c}-0.1301 \\
(-8.11)^{* * *}\end{array}$ & $\begin{array}{l}0.0205 \\
(0.64)\end{array}$ & $\begin{array}{c}0.0143 \\
(0.53)\end{array}$ & $\begin{array}{c}-0.0840 \\
(-4.78) * * *\end{array}$ & $\begin{array}{c}-0.0399 \\
(-1.19)\end{array}$ \\
\hline Defined benefit pensions & & & & & & $\begin{array}{l}0.0009 \\
(1.73)^{*}\end{array}$ \\
\hline Defined contribution pensions & & & & & & $\begin{array}{c}-0.0006 \\
(-0.91)\end{array}$ \\
\hline Number of observations & 224527 & 194976 & 29551 & 81539 & 142988 & 97635 \\
\hline Adjusted R-square & 0.2189 & 0.2041 & 0.2301 & 0.2068 & 0.2222 & 0.2405 \\
\hline
\end{tabular}

$*$,**, and ${ }^{* * *}$, significant at the 10,5 and 1 percent level, respectively. 


\section{Table 6}

\section{Sources of Variation in Leverage and Debt Maturity}

This table presents regressions of both leverage and debt maturity. The results for leverage are reported in Panel A. Panel B reports the results for debt maturity. In both panels, Column (1) reports a fixed effects regression for leverage. Column (3) reports a Fama-MacBeth regression for leverage. Columns (2) and (4) reports the corresponding results for maturity structure. All variables are as defined in Table 2 . Industry dummy variables (two digit SIC codes) are included in Columns (3) and (4). This table also reports the adjusted R-squared and number of firm-year observations. T-statistics are given in parentheses.

\begin{tabular}{|c|c|c|c|c|}
\hline \multirow[b]{2}{*}{ Dependent variable: } & \multicolumn{2}{|c|}{ Fixed effects } & \multicolumn{2}{|c|}{ Fama-MacBeth } \\
\hline & $\begin{array}{l}\text { Total debt/Market } \\
\text { value of the firm }\end{array}$ & $\begin{array}{c}\text { Long-term } \\
\text { debt/Total debt }\end{array}$ & $\begin{array}{l}\text { Total debt/Market } \\
\text { value of the firm }\end{array}$ & $\begin{array}{c}\text { Long-term } \\
\text { debt/Total debt }\end{array}$ \\
\hline Independent variable: & $(1)$ & $(2)$ & (3) & (4) \\
\hline \multicolumn{5}{|l|}{ Firm factors: } \\
\hline Tangible assets/Total assets & $\begin{array}{c}0.1610 \\
(7.23) * * *\end{array}$ & $\begin{array}{c}0.0846 \\
(5.03) * * *\end{array}$ & $\begin{array}{c}0.1964 \\
(17.83)^{* * *}\end{array}$ & $\begin{array}{c}0.2692 \\
(62.65)^{* * *}\end{array}$ \\
\hline ROA & $\begin{array}{c}-0.0260 \\
(-8.29)^{* * *}\end{array}$ & $\begin{array}{c}0.0136 \\
(5.56)^{* * *}\end{array}$ & $\begin{array}{c}-0.1346 \\
(-3.06)^{* * *}\end{array}$ & $\begin{array}{c}0.0684 \\
(13.49)^{* * *}\end{array}$ \\
\hline Log total assets & $\begin{array}{c}0.0110 \\
(4.25) * * *\end{array}$ & $\begin{array}{c}0.0044 \\
(3.74)^{* * *}\end{array}$ & $\begin{array}{c}0.0075 \\
(14.00)^{* * *}\end{array}$ & $\begin{array}{c}0.0143 \\
(21.85)^{* * *}\end{array}$ \\
\hline Market-to-book ratio & $\begin{array}{c}-0.0032 \\
(-5.17)^{* * *}\end{array}$ & $\begin{array}{l}0.0006 \\
(2.92)^{* * *}\end{array}$ & $\begin{array}{c}-0.0085 \\
(-14.16)^{* * *}\end{array}$ & $\begin{array}{l}0.0000 \\
(-0.04)\end{array}$ \\
\hline Country factors: & & & & \\
\hline Developed economy & & & $\begin{array}{c}0.1140 \\
(6.44)^{* * *}\end{array}$ & $\begin{array}{c}0.1536 \\
(12.95)^{* * *}\end{array}$ \\
\hline Inflation rate & $\begin{array}{c}0.1952 \\
(2.15)^{* *}\end{array}$ & $\begin{array}{c}0.0999 \\
(2.12)^{* *}\end{array}$ & $\begin{array}{l}-0.0012 \\
(-0.02)\end{array}$ & $\begin{array}{l}-0.1211 \\
(-0.74)\end{array}$ \\
\hline Inflation rate volatility & $\begin{array}{l}-0.0050 \\
(-0.93)\end{array}$ & $\begin{array}{c}-0.0046 \\
(-2.83)^{* * *}\end{array}$ & $\begin{array}{l}0.1039 \\
(0.62)\end{array}$ & $\begin{array}{l}-0.1100 \\
(-0.91)\end{array}$ \\
\hline Corruption index & $\begin{array}{c}0.0388 \\
(2.59)^{* * *}\end{array}$ & $\begin{array}{l}-0.0206 \\
(-1.97)^{* *}\end{array}$ & $\begin{array}{c}0.0206 \\
(7.89) * * *\end{array}$ & $\begin{array}{c}-0.0363 \\
(-15.76)^{* * *}\end{array}$ \\
\hline Common law & & & $\begin{array}{c}-0.0336 \\
(-6.23) * * *\end{array}$ & $\begin{array}{c}0.0954 \\
(20.04)^{* * *}\end{array}$ \\
\hline Bankruptcy code & & & $\begin{array}{c}0.0184 \\
(4.89)^{* * *}\end{array}$ & $\begin{array}{c}0.0526 \\
(16.63)^{* * *}\end{array}$ \\
\hline Tax & $\begin{array}{l}0.1885 \\
(1.28)\end{array}$ & & $\begin{array}{c}-0.0036 \\
(-0.15)\end{array}$ & \\
\hline Deposits & $\begin{array}{l}0.0293 \\
(0.61)\end{array}$ & $\begin{array}{c}-0.0123 \\
(-0.55)\end{array}$ & $\begin{array}{c}-0.0243 \\
(-2.15)^{* *}\end{array}$ & $\begin{array}{c}-0.1089 \\
(-9.40) * * *\end{array}$ \\
\hline Deposit insurance & $\begin{array}{c}0.0310 \\
(2.78)^{* * *}\end{array}$ & $\begin{array}{l}-0.0051 \\
(-1.01)\end{array}$ & $\begin{array}{l}-0.0005 \\
(-0.17)\end{array}$ & $\begin{array}{l}0.0074 \\
(1.37)\end{array}$ \\
\hline Domestic savings & $\begin{array}{l}-2.7265 \\
(-1.62)\end{array}$ & $\begin{array}{l}0.9638 \\
(1.33)\end{array}$ & $\begin{array}{c}1.1488 \\
(4.14)^{* * *}\end{array}$ & $\begin{array}{c}-4.3573 \\
(-13.62)^{* * *}\end{array}$ \\
\hline Insurance penetration & $\begin{array}{l}0.0368 \\
(0.39)\end{array}$ & $\begin{array}{c}0.0081 \\
(0.05)\end{array}$ & $\begin{array}{c}0.5433 \\
(3.36)^{* * *}\end{array}$ & $\begin{array}{c}-0.2434 \\
(-2.65)^{* * *}\end{array}$ \\
\hline Government bonds & $\begin{array}{l}-0.0240 \\
(-1.09)\end{array}$ & $\begin{array}{c}-0.0777 \\
(-5.42)^{* * *}\end{array}$ & $\begin{array}{l}-0.0403 \\
(-1.70)^{*}\end{array}$ & $\begin{array}{l}0.0002 \\
(0.01)\end{array}$ \\
\hline Number of observations & 251780 & 225437 & 251780 & 225437 \\
\hline Adjusted R-squared & 0.0757 & 0.1089 & 0.1102 & 0.1923 \\
\hline
\end{tabular}

${ }^{* * *}$, and ${ }^{* * *}$, significant at the 10,5 and 1 percent level, respectively. 


\section{Table 7}

\section{Book Debt Ratios}

This table presents regressions for book leverage, defined as is the ratio of total debt to total assets. We further decompose the book leverage ratio into its long-term and short-term components. Column (1) reports the regression for book leverage, defined as is the ratio of total debt to total assets. Column (2) reports the regression for long-term debt ratio, defined as is the ratio of long-term debt to total assets. Column (3) reports the regression for short-term debt ratio, defined as is the ratio of short-term to total assets. All variables are as defined in Table 2 . All regressions include dummy variables for industry (two digit SIC codes). This table also reports the adjusted R-squared and number of firm-year observations. T-statistics are given in parentheses.

Dependent variable Total debt/Total

Assets

Independent variable

\section{Firm Factors:}

Tangible assets/Total assets

ROA

Log total assets

Market-to-book ratio
Long-term debt/Total

Assets

(2)

0.1887

$(46.46)^{* * *}$

$-0.0120$

$(-6.74)^{* * *}$

0.0063

$(23.65)^{* * *}$

$-0.0008$

$(-3.52)^{* * *}$
Short-term debt/Total

Assets

(3)

Country factors:

Developed economy

0.0667

$(6.61)^{* * *}$

$-0.0181$

$(-0.46)$

$-0.0073$

Inflation rate volatility

$(-3.89) * * *$

Corruption index

0.0124

$(5.34)^{* * *}$

$-0.0200$

Common law

$(-5.51)^{* * * *}$

Bankruptcy code

0.0124

$(6.92)^{* * *}$

Tax

0.1121

$(8.70)^{* * *}$

Deposits/GDP

$-0.0163$

$(-4.04)^{* * *}$

0.0004

$(0.27)$

0.0054

$(2.65)^{* * * *}$

$-0.0545$

$(-0.84)$

$-0.0337$

$(-3.56)^{* * *}$

224527

Number of observations

0.1474

0.0748

$(9.28)^{* * *}$

$-0.0141$

$(-0.66)$

$-0.0003$

$(-0.15)$

$-0.0032$

$(-1.90)^{* * *}$

0.0214

$(5.34)^{* * *}$

0.0194

$(14.51)^{* * *}$

0.0110

$(3.35)^{* * *}$

$-0.0643$

$(-28.23)^{* * *}$

$-0.0019$

$(-4.49) * * *$

$-0.0010$

$(-4.68)^{* * *}$

Insurance penetration

$-0.0402$

0.0281

$(-11.55)^{* * *}$

0.0043

$(3.31)^{* * *}$

$-0.0069$

$(-4.74)^{* * * *}$

0.0393

(0.77)

$-0.0306$

$(10.06)^{* * *}$

$-0.0053$

$(-4.30)^{* * *}$

0.0118

$(10.96)^{* * *}$

0.0233

(0.63)

$-0.0011$

$(-4.01)^{* * * *}$

$(-0.19)$

224527

224527

0.1802

0.1676 


\section{Appendix 1}

\section{Definitions and data sources of country level variables}

\begin{tabular}{|c|c|c|}
\hline Variable & Description & Source \\
\hline Developed economy & $\begin{array}{l}\text { A zero or one dummy variable indicating whether the } \\
\text { country is classified as developed according to the World } \\
\text { Bank classification based on countries' gross national } \\
\text { income levels }\end{array}$ & $\begin{array}{l}\text { World Development } \\
\text { Indicators, World Bank }\end{array}$ \\
\hline Inflation rate & Annual rate of change on Consumer Price Index & $\begin{array}{l}\text { World Development } \\
\text { Indicators, World Bank }\end{array}$ \\
\hline Inflation rate volatility & & World Development \\
\hline Corruption index & $\begin{array}{l}\text { Standard deviation of inflation rates from period } \mathrm{t}-4 \text { to } \mathrm{t} \\
\text { An index ranges from } 0 \text { to } 10 \text {, with larger value indicating } \\
\text { more severe corruption }\end{array}$ & $\begin{array}{l}\text { Indicators, World Bank } \\
\text { Corruption Perception } \\
\text { Index, Transparency } \\
\text { International }\end{array}$ \\
\hline Common law & $\begin{array}{l}\text { An zero or one dummy variable indicating whether a } \\
\text { country adopts the common law system }\end{array}$ & Treisman [2000] \\
\hline Bankruptcy code & $\begin{array}{l}\text { A proxy for the existence of an explicit bankruptcy code, } \\
\text { measured as a dummy variable equal to } 1 \text { if an insolvent } \\
\text { firm is most likely to undergo a reorganization proceeding. }\end{array}$ & $\begin{array}{l}\text { Djankov, Hart, McLiesh, } \\
\text { Shleifer (2008) }\end{array}$ \\
\hline Tax & $\begin{array}{l}\text { Estimate of the miller tax ratio equal to }(1-[(\text { after all tax } \\
\text { value of } \$ \text { dividends }) /(\text { after all tax value of } \$ \text { interest })]) \\
\text { calculated using statutory tax rates }\end{array}$ & $\begin{array}{l}\text { Price Waterhouse Coopers, } \\
\text { Doing Business }\end{array}$ \\
\hline Deposits & $\begin{array}{l}\text { A proxy for the degree of financial intermediation of a } \\
\text { country, measure as the country's deposits (liquid liability) } \\
\text { over GDP }\end{array}$ & $\begin{array}{l}\text { International Financial } \\
\text { Statistics, International } \\
\text { Monetary Fund }\end{array}$ \\
\hline Deposit insurance & $\begin{array}{l}\text { Dummy variable equal to } 1 \text { if bank deposits are insured by } \\
\text { government }\end{array}$ & $\begin{array}{l}\text { Demirguc-Kunt, } \\
\text { Karacaovali, Laeven (2005) }\end{array}$ \\
\hline Domestic savings & $\begin{array}{l}\text { A proxy for the level of domestic savings measure as the } \\
\text { country's gross domestic saving over GDP. }\end{array}$ & $\begin{array}{l}\text { International Financial } \\
\text { Statistics, International } \\
\text { Monetary Fund }\end{array}$ \\
\hline Insurance penetration & $\begin{array}{l}\text { Value of total insurance premiums/GDP. Total insurance } \\
\text { premium are the sum of life and non-life insurance } \\
\text { premiums. }\end{array}$ & $\begin{array}{l}\text { Swiss Reinsurance } \\
\text { Company } \\
\text { Beck, Demirgüç-Kunt } \\
(2009)\end{array}$ \\
\hline $\begin{array}{l}\text { Pension fund } \\
\text { regulation index }\end{array}$ & $\begin{array}{l}\text { An index of relative restrictions on debt and equity } \\
\text { holdings of pension funds measured as the ratio of the } \\
\text { proportional limit on equity holdings over the proportional } \\
\text { limit on debt holdings, with larger values indicating tighter } \\
\text { restriction on bond holdings. The index ranges from } 1 \text { to } \\
4 \text {. }\end{array}$ & $\begin{array}{l}\text { OECD, Survey of } \\
\text { Investment Regulation of } \\
\text { Pension Funds }\end{array}$ \\
\hline Government bonds & $\begin{array}{l}\text { Value of domestically denominated government } \\
\text { bonds/GDP }\end{array}$ & $\begin{array}{l}\text { International Financial } \\
\text { Statistics, International } \\
\text { Monetary Fund }\end{array}$ \\
\hline $\begin{array}{l}\text { Defined benefit } \\
\text { pensions }\end{array}$ & Value of defined benefit pension fund assets/GDP. & OECD \\
\hline $\begin{array}{l}\text { Defined contribution } \\
\text { pensions }\end{array}$ & Value of defined contribution pension fund assets/GDP & OECD \\
\hline
\end{tabular}


Appendix 2

Median values of country level dependent variables

The table provides the median value of country level the dependent variables, classified by country. Variables are as defined in Table 2 and Appendix 1

\begin{tabular}{|c|c|c|c|c|c|c|c|c|c|c|c|c|c|c|c|}
\hline Country & $\begin{array}{c}\text { Developed } \\
\text { economy }\end{array}$ & $\begin{array}{l}\text { Inflation } \\
\text { rate }\end{array}$ & $\begin{array}{c}\text { Inflation rate } \\
\text { volatility }\end{array}$ & $\begin{array}{c}\text { Corruption } \\
\text { index }\end{array}$ & $\begin{array}{c}\text { Common } \\
\text { law }\end{array}$ & $\begin{array}{c}\text { Bankruptcy } \\
\text { code }\end{array}$ & Tax & Deposits / GDP & $\begin{array}{c}\text { Deposit } \\
\text { insurance }\end{array}$ & $\begin{array}{c}\text { Domestic } \\
\text { savings }\end{array}$ & $\begin{array}{c}\text { Insurance } \\
\text { penetration }\end{array}$ & $\begin{array}{c}\text { Pension fund } \\
\text { regulation index }\end{array}$ & $\begin{array}{c}\text { Government } \\
\text { bonds }\end{array}$ & $\begin{array}{l}\text { Defined } \\
\text { benefit } \\
\text { pension }\end{array}$ & $\begin{array}{c}\text { Defined } \\
\text { contribution } \\
\text { pension } \\
\end{array}$ \\
\hline Australia & 1.00 & 0.03 & 0.01 & 1.40 & 1.00 & 0.00 & 0.00 & 0.60 & 0.00 & 0.23 & 0.04 & 2.00 & 0.09 & . & . \\
\hline Austria & 1.00 & 0.02 & 0.01 & 2.35 & 0.00 & 0.00 & 0.01 & 0.82 & 1.00 & 0.25 & 0.02 & 1.00 & 0.47 & . & . \\
\hline Belgium & 1.00 & 0.02 & 0.01 & 2.90 & 0.00 & 1.00 & -0.02 & 0.78 & 1.00 & 0.24 & 0.04 & 2.00 & 0.81 & 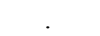 & \\
\hline Brazil & 0.00 & 0.08 & 0.10 & 6.35 & 0.00 & 0.00 & 0.15 & 0.37 & 1.00 & 0.18 & 0.00 & 1.00 & 0.32 & 12.36 & 5.88 \\
\hline Canada & 1.00 & 0.02 & 0.01 & 1.03 & 1.00 & 1.00 & 0.19 & 0.75 & 1.00 & 0.23 & 0.03 & 2.00 & 0.28 & 52.52 & 1.49 \\
\hline Switzerland & 1.00 & 0.01 & 0.01 & 1.10 & 0.00 & 1.00 & 0.30 & 1.25 & 1.00 & 0.28 & 0.07 & 2.00 & 0.11 & . & 102.87 \\
\hline Chile & 0.00 & 0.05 & 0.02 & 2.85 & 0.00 & 0.00 & 0.17 & 0.43 & 1.00 & 0.26 & 0.02 & 1.00 & 0.28 & . & 59.08 \\
\hline China & 0.00 & 0.02 & 0.07 & 6.60 & 0.00 & 0.00 & 0.30 & 0.33 & 0.00 & 0.42 & 0.01 & 2.00 & 0.15 & . & . \\
\hline Germany & 1.00 & 0.02 & 0.01 & 1.94 & 0.00 & 0.00 & 0.00 & 0.70 & 1.00 & 0.22 & 0.03 & 2.00 & 0.28 & & \\
\hline Denmark & 1.00 & 0.02 & 0.00 & 0.50 & 0.00 & 0.00 & 0.05 & 0.53 & 1.00 & 0.25 & 0.04 & 2.00 & 0.57 & 2.71 & 26.92 \\
\hline Spain & 1.00 & 0.03 & 0.01 & 3.35 & 0.00 & 1.00 & 0.18 & 0.65 & 1.00 & 0.23 & 0.02 & 3.00 & 0.32 & 0.10 & 6.32 \\
\hline Finland & 1.00 & 0.01 & 0.01 & 0.40 & 0.00 & 1.00 & 0.00 & 0.48 & 1.00 & 0.26 & 0.07 & 3.00 & 0.37 & 57.85 & . \\
\hline France & 1.00 & 0.02 & 0.00 & 3.00 & 0.00 & 1.00 & 0.17 & 0.63 & 1.00 & 0.20 & 0.06 & 3.00 & 0.39 & 1.16 & . \\
\hline United Kingdom & 1.00 & 0.03 & 0.01 & 1.52 & 1.00 & 0.00 & 0.13 & 0.90 & 1.00 & 0.16 & 0.09 & 3.00 & 0.33 & . & . \\
\hline Greece & 1.00 & 0.04 & 0.02 & 5.25 & 0.00 & 0.00 & -0.18 & 0.55 & 1.00 & 0.10 & 0.01 & 3.00 & 0.74 & 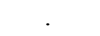 & \\
\hline Hong Kong, & 1.00 & 0.02 & 0.02 & 2.25 & 1.00 & 0.00 & 0.16 & 1.92 & 0.00 & 0.31 & 0.03 & . & 0.09 & 5.71 & 15.07 \\
\hline Indonesia & 0.00 & 0.09 & 0.03 & 8.10 & 0.00 & 1.00 & 0.30 & 0.39 & 1.00 & 0.31 & 0.01 & . & 0.21 & . & . \\
\hline India & 0.00 & 0.06 & 0.03 & 7.20 & 1.00 & 0.00 & 0.35 & 0.38 & 1.00 & 0.23 & 0.01 & . & 0.20 & . & . \\
\hline Ireland & 1.00 & 0.03 & 0.01 & 2.50 & 1.00 & 1.00 & 0.13 & 0.70 & 1.00 & 0.36 & 0.07 & 3.00 & 0.36 & 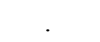 & \\
\hline Israel & 1.00 & 0.04 & 0.02 & 2.95 & 1.00 & 0.00 & 0.36 & 0.74 & 0.00 & 0.17 & 0.03 & 3.00 & 0.00 & 24.11 & 4.13 \\
\hline Italy & 1.00 & 0.03 & 0.01 & 5.25 & 0.00 & 1.00 & 0.00 & 0.53 & 1.00 & 0.22 & 0.03 & 4.00 & 0.80 & 0.46 & 2.04 \\
\hline Japan & 1.00 & 0.00 & 0.01 & 2.90 & 0.00 & 1.00 & 0.35 & 1.94 & 1.00 & 0.27 & 0.09 & 4.00 & 0.60 & 10.79 & 0.56 \\
\hline Korea, Rep. & 1.00 & 0.04 & 0.02 & 5.76 & 0.00 & 1.00 & 0.28 & 0.49 & 1.00 & 0.35 & 0.09 & 1.00 & 0.11 & 0.50 & . \\
\hline Mexico & 0.00 & 0.10 & 0.08 & 6.70 & 0.00 & 1.00 & 0.04 & 0.23 & 1.00 & 0.22 & 0.01 & 1.00 & 0.15 & 3.09 & 6.04 \\
\hline Malaysia & 0.00 & 0.03 & 0.01 & 4.90 & 1.00 & 0.00 & 0.28 & 1.12 & 1.00 & 0.43 & 0.02 & 1.00 & 0.34 & . & . \\
\hline Netherlands & 1.00 & 0.02 & 0.01 & 1.05 & 0.00 & 0.00 & 0.35 & 0.99 & 1.00 & 0.27 & 0.05 & 4.00 & 0.42 & & . \\
\hline Norway & 1.00 & 0.02 & 0.01 & 1.25 & 0.00 & 1.00 & 0.00 & 0.50 & 1.00 & 0.31 & 0.02 & 4.00 & 0.12 & 6.51 & \\
\hline New Zealand & 1.00 & 0.02 & 0.01 & 0.60 & 1.00 & 0.00 & 0.00 & 0.82 & 0.00 & 0.23 & 0.02 & 4.00 & 0.27 & 3.28 & 8.53 \\
\hline Pakistan & 0.00 & 0.08 & 0.02 & 7.80 & 1.00 & 0.00 & 0.45 & 0.30 & 0.00 & 0.16 & 0.00 & . & 0.36 & . & . \\
\hline Peru & 0.00 & 0.04 & 0.04 & 5.90 & 0.00 & 1.00 & 0.30 & 0.21 & 1.00 & 0.18 & 0.00 & . & 0.02 & . & 10.45 \\
\hline Philippines & 0.00 & 0.07 & 0.02 & 7.40 & 0.00 & 1.00 & 0.33 & 0.47 & 1.00 & 0.15 & 0.01 & . & 0.35 & . & \\
\hline Portugal & 1.00 & 0.03 & 0.01 & 3.65 & 0.00 & 1.00 & 0.18 & 0.88 & 1.00 & 0.17 & 0.02 & 2.00 & 0.40 & 11.07 & 0.48 \\
\hline Singapore & 1.00 & 0.02 & 0.01 & 0.82 & 1.00 & 0.00 & 0.26 & 0.98 & 0.00 & 0.47 & 0.03 & . & 0.40 & . & . \\
\hline Sweden & 1.00 & 0.02 & 0.01 & 0.80 & 0.00 & 0.00 & -0.03 & 0.40 & 1.00 & 0.24 & 0.04 & 1.00 & 0.39 & . & \\
\hline Thailand & 0.00 & 0.04 & 0.01 & 6.80 & 1.00 & 1.00 & 0.00 & 0.94 & 1.00 & 0.34 & 0.01 & . & 0.02 & . & 4.72 \\
\hline Turkey & 0.00 & 0.54 & 0.05 & 6.40 & 0.00 & 1.00 & -0.17 & 0.32 & 1.00 & 0.17 & 0.00 & 4.00 & 0.21 & 0.38 & 0.19 \\
\hline Taiwan & 1.00 & 0.01 & 0.01 & 4.45 & 0.00 & 1.00 & 0.03 & 0.24 & 1.00 & 0.14 & 0.04 & $\cdot$ & 0.13 & . & \\
\hline United States & 1.00 & 0.03 & 0.01 & 2.40 & 1.00 & 1.00 & 0.35 & 0.65 & 1.00 & 0.16 & 0.04 & 4.00 & 0.29 & 48.11 & 32.24 \\
\hline South Africa & 0.00 & 0.07 & 0.02 & 5.30 & 1.00 & 0.00 & 0.30 & 0.50 & 0.00 & 0.19 & 0.11 & 2.00 & 0.46 & . & 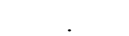 \\
\hline
\end{tabular}




\section{Appendix 3 \\ Pooled firm-level regressions of leverage by country}

The table presents the regression of leverage on firm level variables as defined in Table 2. The regression equation is estimated for each country using the pooled time-series and cross-sectional sample. All regressions include dummy variables for industry (two digit SIC codes). This table also reports the adjusted R-squared and number of firm-year observations. Standard errors are robust to clustering within firm over time. T-statistics are given in parentheses.

\begin{tabular}{|c|c|c|c|c|c|}
\hline Country Code & $\begin{array}{l}\text { Tangible assets/ } \\
\text { Total Assets }\end{array}$ & ROA & Log total assets & $\begin{array}{l}\text { Market-to-book } \\
\text { ratio }\end{array}$ & $\begin{array}{l}\text { No of observations/ } \\
\text { Adjusted R-squared }\end{array}$ \\
\hline \multirow[t]{2}{*}{ Australia } & 0.0343 & -0.0061 & 0.0264 & -0.0072 & 8221 \\
\hline & $(2.11)^{* *}$ & $(-1.02)$ & $(9.49)^{* * *}$ & $(-9.11)^{* * *}$ & 0.1224 \\
\hline \multirow[t]{2}{*}{ Austria } & 0.2481 & -0.0735 & 0.0133 & -0.0128 & 1093 \\
\hline & $(2.86)^{* * *}$ & $(-1.74) *$ & $(2.78) * * *$ & $(-3.59)^{* * *}$ & 0.1129 \\
\hline \multirow[t]{2}{*}{ Belgium } & 0.1931 & -0.5328 & 0.016 & -0.0132 & 1406 \\
\hline & $(3.61) * * *$ & $(-4.34)^{* * *}$ & $(5.31)^{* * *}$ & $(-3.73)^{* * *}$ & 0.1824 \\
\hline \multirow[t]{2}{*}{ Brazil } & 0.1930 & -0.1741 & -0.0010 & -0.0103 & 2579 \\
\hline & $(3.09)^{* * *}$ & $(-2.81)^{* * *}$ & $(-0.31)$ & $(-3.33)^{* * *}$ & 0.0814 \\
\hline \multirow[t]{2}{*}{ Canada } & 0.0924 & 0.0070 & 0.0165 & -0.0102 & 10806 \\
\hline & $(5.13)^{* * *}$ & $(0.78)$ & $(4.05)^{* * *}$ & $(-13.46)^{* * *}$ & 0.1003 \\
\hline \multirow[t]{2}{*}{ Switzerland } & 0.3178 & -0.1171 & 0.0036 & -0.0186 & 2583 \\
\hline & $(7.63) * * *$ & $(-2.14) * *$ & $(0.83)$ & $(-5.97) * * *$ & 0.1926 \\
\hline \multirow[t]{2}{*}{ Chile } & 0.0817 & -0.1870 & 0.0181 & -0.0091 & 1413 \\
\hline & $(1.56)$ & $(-1.01)$ & $(1.87)^{*}$ & $(-2.91)^{* * *}$ & 0.0840 \\
\hline \multirow[t]{2}{*}{ China } & 0.0490 & -0.1378 & 0.0423 & -0.0073 & 6815 \\
\hline & $(2.10)^{* *}$ & $(-5.87)^{* * *}$ & $(5.26)^{* * *}$ & $(-6.85)^{* * *}$ & 0.1221 \\
\hline \multirow[t]{2}{*}{ Germany } & 0.3018 & -0.0520 & 0.0056 & -0.0111 & 8497 \\
\hline & $(9.41) * * *$ & $(-3.02)$ & $(3.73)$ & $(-9.43)$ & 0.1106 \\
\hline \multirow[t]{2}{*}{ Denmark } & 0.2503 & -0.0762 & 0.0003 & -0.0193 & 2006 \\
\hline & $(4.27)^{* * *}$ & $(-1.74)^{*}$ & $(0.08)$ & $(-6.15)^{* * *}$ & 0.1368 \\
\hline \multirow[t]{2}{*}{ Spain } & 0.0767 & -0.8292 & 0.0019 & -0.0127 & 2025 \\
\hline & $(1.76)^{*}$ & $(-6.83) * * *$ & $(0.85)$ & $(-3.57) * * *$ & 0.1600 \\
\hline \multirow[t]{2}{*}{ Finland } & 0.4595 & -0.2516 & 0.0055 & -0.0149 & 1591 \\
\hline & $(7.57)^{* * *}$ & $(-2.68)^{* * *}$ & $(1.78) *$ & $(-4.19)^{* * *}$ & 0.2493 \\
\hline \multirow[t]{2}{*}{ France } & 0.3408 & -0.1791 & 0.0081 & -0.0134 & 9063 \\
\hline & $(10.19)^{* * *}$ & $(-3.48)^{* * *}$ & $(4.35)^{* * *}$ & $(-13.25)^{* * *}$ & 0.1624 \\
\hline \multirow{2}{*}{ United Kingdom } & 0.2412 & -0.0126 & -0.0035 & -0.0070 & 20741 \\
\hline & $(18.10) * * *$ & $(-1.93) *$ & $(-2.81) * * *$ & $(-16.15) * * *$ & 0.1289 \\
\hline \multirow[t]{2}{*}{ Greece } & 0.0335 & -1.2120 & 0.0239 & -0.0076 & 2471 \\
\hline & $(0.72)$ & $(-8.47)^{* * *}$ & $(3.30)^{* * *}$ & $(-7.50) * * *$ & 0.2250 \\
\hline \multirow[t]{2}{*}{ Hong Kong } & 0.2220 & -0.0512 & 0.0035 & -0.0130 & 6493 \\
\hline & $(7.69)^{* * *}$ & $(-4.03)^{* * *}$ & $(1.84)^{*}$ & $(-10.85)^{* * *}$ & 0.0982 \\
\hline \multirow[t]{2}{*}{ Indonesia } & 0.2525 & -0.5076 & 0.0034 & -0.0145 & 2452 \\
\hline & $(4.55)^{* * *}$ & $(-5.01)^{* * *}$ & $(0.70)$ & $(-5.10) * * *$ & 0.1586 \\
\hline \multirow[t]{2}{*}{ India } & 0.4351 & -1.3180 & -0.0052 & -0.0192 & 4381 \\
\hline & $(11.03)^{* * *}$ & $(-13.25)^{* * *}$ & $(-1.16)$ & $(-8.95) * * *$ & 0.4328 \\
\hline Ireland & 0.2047 & 0.0234 & 0.0065 & -0.0091 & 854 \\
\hline & $(3.49) * * *$ & $(1.67) *$ & (1.09) & $(-3.74) * * *$ & 0.1095 \\
\hline Israel & 0.5941 & -0.0212 & 0.0221 & -0.0081 & 934 \\
\hline & $(7.69)^{* * *}$ & $(-0.54)$ & $(1.76)^{*}$ & $(-3.06)^{* *}$ & 0.3667 \\
\hline Italy & 0.1041 & -0.5515 & 0.0117 & -0.0213 & 2644 \\
\hline & $(1.80)^{*}$ & $(-2.89)^{* * *}$ & $(2.81)^{* * *}$ & $(-6.68)^{* * *}$ & 0.1169 \\
\hline Japan & 0.3655 & -0.6499 & 0.0096 & -0.0055 & 41763 \\
\hline & $(18.55)^{* * *}$ & $(-6.60)^{* * *}$ & $(4.70)^{* * *}$ & $(-6.05)^{* * *}$ & 0.1116 \\
\hline Korea & 0.1765 & -0.1977 & 0.0595 & -0.0201 & 6734 \\
\hline & $(4.46)^{* * *}$ & $(-4.92)^{* * *}$ & $(7.65)^{* * *}$ & $(-6.03)^{* * * *}$ & 0.1764 \\
\hline Mexico & 0.0821 & -0.8375 & 0.0143 & -0.0392 & 1224 \\
\hline & $(1.03)$ & $(-4.14)^{* * *}$ & $(1.31)$ & $(-3.27)^{* * *}$ & 0.2132 \\
\hline Malaysia & 0.1179 & -0.3592 & 0.0079 & -0.0123 & 7072 \\
\hline & $(3.77)^{* * *}$ & $(-6.27)^{* * *}$ & $(3.76)^{* * *}$ & $(-7.05) * * *$ & 0.1093 \\
\hline Netherlands & 0.2754 & -0.0994 & 0.0049 & -0.0108 & 2482 \\
\hline & $(6.05)^{* * *}$ & $(-4.19)^{* * *}$ & $(1.55)$ & $(-6.52)^{* * *}$ & 0.1594 \\
\hline Norway & 0.5780 & -0.0231 & 0.0049 & -0.0145 & 1757 \\
\hline & $(19.03)^{* * *}$ & $(-0.90)$ & $(1.61)$ & $(-5.47)^{* * *}$ & 0.4568 \\
\hline New Zealand & 0.1006 & 0.0022 & 0.0033 & -0.0150 & 917 \\
\hline & $(1.68) *$ & $(0.11)$ & $(0.38)$ & $(-2.29)^{* *}$ & \\
\hline
\end{tabular}




\begin{tabular}{|c|c|c|c|c|c|}
\hline Pakistan & $\begin{array}{c}0.3415 \\
(5.13)^{* * *}\end{array}$ & $\begin{array}{c}-1.5769 \\
(-9.76) * * *\end{array}$ & $\begin{array}{l}-0.0064 \\
(-0.67)\end{array}$ & $\begin{array}{c}-0.0197 \\
(-3.67)^{* * *}\end{array}$ & $\begin{array}{c}1045 \\
0.4428\end{array}$ \\
\hline Peru & $\begin{array}{c}0.0169 \\
(0.15)\end{array}$ & $\begin{array}{c}-1.3765 \\
(-8.23)^{* * *}\end{array}$ & $\begin{array}{l}0.0157 \\
(1.17)\end{array}$ & $\begin{array}{l}-0.0167 \\
(-1.50)\end{array}$ & $\begin{array}{c}491 \\
0.2523\end{array}$ \\
\hline Philippines & $\begin{array}{c}0.1738 \\
(2.46) * *\end{array}$ & $\begin{array}{c}-0.1420 \\
(-2.92)^{* * *}\end{array}$ & $\begin{array}{c}0.0217 \\
(5.16)^{* * *}\end{array}$ & $\begin{array}{c}-0.0201 \\
(-4.46) * * *\end{array}$ & $\begin{array}{c}1523 \\
0.1484\end{array}$ \\
\hline Portugal & $\begin{array}{c}-0.2483 \\
(-3.15)^{* * *}\end{array}$ & $\begin{array}{c}-0.7286 \\
(-2.66) * * *\end{array}$ & $\begin{array}{c}0.0113 \\
(1.67) *\end{array}$ & $\begin{array}{c}-0.0301 \\
(-4.99)^{* * *}\end{array}$ & $\begin{array}{c}840 \\
0.1775\end{array}$ \\
\hline Singapore & $\begin{array}{c}0.2632 \\
(8.63)^{* * *}\end{array}$ & $\begin{array}{c}-0.0783 \\
(-2.32)^{* *}\end{array}$ & $\begin{array}{c}0.0080 \\
(2.39)^{* *}\end{array}$ & $\begin{array}{c}-0.0186 \\
(-6.50)^{* * *}\end{array}$ & $\begin{array}{c}3973 \\
0.1290\end{array}$ \\
\hline Sweden & $\begin{array}{c}0.4990 \\
(13.16)^{* * *}\end{array}$ & $\begin{array}{l}0.0115 \\
(0.79)\end{array}$ & $\begin{array}{c}-0.0016 \\
(-0.43)\end{array}$ & $\begin{array}{c}-0.0161 \\
(-8.47)^{* * *}\end{array}$ & $\begin{array}{c}3189 \\
0.3777\end{array}$ \\
\hline Thailand & $\begin{array}{c}0.0853 \\
(2.09)^{* *}\end{array}$ & $\begin{array}{c}-0.5986 \\
(-3.77) * * *\end{array}$ & $\begin{array}{c}0.0290 \\
(3.80)^{* * *}\end{array}$ & $\begin{array}{c}-0.0128 \\
(-3.28)^{* * *}\end{array}$ & $\begin{array}{c}3403 \\
0.1505\end{array}$ \\
\hline Turkey & $\begin{array}{c}-0.0963 \\
(-1.54)\end{array}$ & $\begin{array}{c}-0.5521 \\
(-5.16)^{* * *}\end{array}$ & $\begin{array}{c}0.0114 \\
(1.98)^{* *}\end{array}$ & $\begin{array}{c}-0.0063 \\
(-3.02)^{* *}\end{array}$ & $\begin{array}{c}1422 \\
0.1925\end{array}$ \\
\hline Taiwan & $\begin{array}{l}0.0505 \\
(1.90)^{*}\end{array}$ & $\begin{array}{c}-0.8067 \\
(-10.40)^{* * *}\end{array}$ & $\begin{array}{c}0.0395 \\
(10.21)^{* * *}\end{array}$ & $\begin{array}{c}-0.0411 \\
(-9.31)^{* * *}\end{array}$ & $\begin{array}{c}7051 \\
0.3186\end{array}$ \\
\hline United States & $\begin{array}{c}0.2774 \\
(33.04)^{* * *}\end{array}$ & $\begin{array}{c}0.0052 \\
(2.66) * * *\end{array}$ & $\begin{array}{c}0.0020 \\
(3.19)^{* * *}\end{array}$ & $\begin{array}{c}-0.0072 \\
(-38.41) * * *\end{array}$ & $\begin{array}{l}77132 \\
0.1076\end{array}$ \\
\hline South Africa & $\begin{array}{c}0.0780 \\
(2.39)^{* *}\end{array}$ & $\begin{array}{l}-0.0442 \\
(-1.65)^{*}\end{array}$ & $\begin{array}{c}-0.0110 \\
(-4.35) * * *\end{array}$ & $\begin{array}{c}-0.0073 \\
(-4.18) * * *\end{array}$ & $\begin{array}{r}3483 \\
0.0622 \\
\end{array}$ \\
\hline
\end{tabular}

***, and ${ }^{* *}$, significant at the 10,5 and 1 percent level, respectively. 


\section{Appendix 4 \\ Pooled firm-level regressions of debt maturity structure by country}

The table presents the regression of debt maturity on firm level variables as defined in Table 2 . The regression equation is estimated for each country using the pooled time-series and cross-sectional sample. All regressions include dummy variables for industry (two digit SIC codes). This table also reports the adjusted R-squared and number of firm-year observations. Standard errors are robust to clustering within firm over time. T-statistics are given in parentheses.

\begin{tabular}{|c|c|c|c|c|c|}
\hline Country Code & $\begin{array}{l}\text { Tangible assets/ } \\
\text { Total Assets }\end{array}$ & ROA & Log total assets & $\begin{array}{l}\text { Market-to-book } \\
\text { ratio }\end{array}$ & $\begin{array}{l}\text { No of observations/ } \\
\text { Adjusted R-squared }\end{array}$ \\
\hline \multirow[t]{2}{*}{ Australia } & 0.1720 & 0.0487 & 0.0344 & -0.0011 & 6292 \\
\hline & $(6.15)^{* * *}$ & $(3.15)^{* * *}$ & $(6.54)^{* * *}$ & $(-0.72)$ & 0.0991 \\
\hline \multirow[t]{2}{*}{ Austria } & 0.3808 & -0.1207 & -0.0006 & 0.0005 & 1025 \\
\hline & $(3.72) * * *$ & $(-1.65)$ & $(-0.09)$ & $(0.10)$ & 0.0674 \\
\hline \multirow[t]{2}{*}{ Belgium } & 0.4061 & 0.0641 & 0.0167 & 0.0028 & 1370 \\
\hline & $(5.63)^{* * *}$ & $(0.50)$ & $(3.84)^{* * *}$ & $(1.14)$ & 0.1333 \\
\hline \multirow[t]{2}{*}{ Brazil } & 0.3386 & 0.1300 & 0.0217 & 0.0045 & 2551 \\
\hline & $(6.98)^{* * *}$ & $(4.17)^{* * *}$ & $(5.58)^{* * *}$ & $(1.99) * *$ & 0.1304 \\
\hline \multirow[t]{2}{*}{ Canada } & 0.2135 & 0.0469 & 0.0282 & -0.0018 & 8672 \\
\hline & $(8.97)^{* * *}$ & $(3.05)^{* * *}$ & $(5.70)^{* * *}$ & $(-1.49)$ & 0.1144 \\
\hline \multirow[t]{2}{*}{ Switzerland } & 0.3620 & 0.0296 & -0.0016 & -0.0055 & 2500 \\
\hline & $(7.95) * * *$ & $(0.43)$ & $(-0.33)$ & $(-1.58)$ & 0.1005 \\
\hline \multirow[t]{2}{*}{ Chile } & 0.3038 & -0.1973 & 0.0440 & 0.0086 & 1301 \\
\hline & $(3.32)^{* * *}$ & $(-1.23)$ & $(1.87)^{*}$ & $(1.47)$ & 0.1269 \\
\hline \multirow[t]{2}{*}{ China } & 0.3953 & 0.0590 & 0.0422 & 0.0006 & 6499 \\
\hline & $(8.65)^{* * *}$ & $(2.43)^{* *}$ & $(2.35)^{* *}$ & $(0.37)$ & 0.1570 \\
\hline \multirow[t]{2}{*}{ Germany } & 0.4253 & 0.0480 & -0.0019 & 0.0021 & 7523 \\
\hline & $(12.06) * * *$ & $(1.76)^{*}$ & $(-1.06)$ & $(1.52)$ & 0.0846 \\
\hline \multirow[t]{2}{*}{ Denmark } & 0.4435 & -0.0095 & -0.0046 & 0.0031 & 1931 \\
\hline & $(7.00)^{* * *}$ & $(-0.30)^{* *}$ & $(-1.07)$ & $(0.85)$ & 0.1098 \\
\hline \multirow[t]{2}{*}{ Spain } & 0.3516 & -0.1312 & -0.0036 & 0.0059 & 1967 \\
\hline & $(6.46)^{* * *}$ & $(-1 . .00)$ & $(-1.25)$ & $(1.36)$ & 0.0726 \\
\hline \multirow[t]{2}{*}{ Finland } & 0.2129 & -0.1358 & 0.0024 & -0.0040 & 1551 \\
\hline & $(4.04)$ & $(-2.27)^{* *}$ & $(0.61)$ & $(-1.22)$ & 0.0512 \\
\hline \multirow[t]{2}{*}{ France } & 0.3438 & -0.0037 & 0.0062 & 0.0008 & 8972 \\
\hline & $(11.21)^{* * *}$ & $(-0.11)$ & $(2.93)^{* * *}$ & $(0.65)$ & 0.0612 \\
\hline \multirow[t]{2}{*}{ United Kingdom } & 0.3790 & 0.0243 & 0.0077 & 0.0003 & 18605 \\
\hline & $(20.40) * * *$ & $(2.14) * *$ & $(4.55) * * *$ & $(0.41)$ & 0.0897 \\
\hline \multirow[t]{2}{*}{ Greece } & 0.4844 & 0.4544 & 0.0157 & -0.0012 & 2262 \\
\hline & $(7.06)^{* * *}$ & $(3.14) * * *$ & $(1.20)$ & $(-0.71)$ & 0.1062 \\
\hline \multirow[t]{2}{*}{ Hong Kong } & 0.3965 & 0.0127 & 0.0012 & 0.0019 & 5862 \\
\hline & $(10.76)^{* * *}$ & $(0.75)$ & $(0.45)$ & $(1.22)$ & 0.0786 \\
\hline \multirow[t]{2}{*}{ Indonesia } & 0.3888 & 0.2320 & 0.0088 & 0.0028 & 2280 \\
\hline & $(6.15)^{* * *}$ & $(4.72)^{* * *}$ & $(1.51)$ & $(1.00)$ & 0.0841 \\
\hline \multirow[t]{2}{*}{ India } & 0.4336 & 0.0711 & 0.0208 & 0.0012 & 4286 \\
\hline & $(10.01)^{* * *}$ & $(0.87)$ & $(3.00)^{* * *}$ & $(0.57)$ & 0.1092 \\
\hline Ireland & 0.3475 & 0.0875 & 0.0210 & 0.0033 & 766 \\
\hline & $(4.67)^{* * *}$ & $(2.26) * *$ & $(2.67) * * *$ & $(0.95)$ & 0.1232 \\
\hline Israel & 0.3784 & -0.0453 & 0.0283 & -0.0008 & 750 \\
\hline & $(5.21)^{* *}$ & $(-0.65)$ & $(2.42)^{* *}$ & $(-0.21)$ & 0.1572 \\
\hline Italy & 0.2976 & 0.2107 & 0.0088 & -0.0002 & 2589 \\
\hline & $(5.44) * * *$ & $(2.78)^{* * *}$ & $(1.87)^{*}$ & $(-0.08)$ & 0.0650 \\
\hline Japan & 0.4001 & 0.1380 & 0.0118 & 0.0038 & 38813 \\
\hline & $(22.97)^{* * *}$ & $(3.91)^{* * *}$ & $(6.72)^{* * *}$ & $(4.97)^{* * *}$ & 0.0754 \\
\hline Korea & 0.1406 & -0.0917 & 0.0223 & 0.0049 & 6303 \\
\hline & $(4.07)^{* * *}$ & $(-3.18)^{* *}$ & $(3.62)^{* * *}$ & $(2.14)^{* *}$ & 0.0353 \\
\hline Mexico & 0.3308 & 0.3566 & 0.0531 & 0.0033 & 1159 \\
\hline & $(3.98)^{* * *}$ & $(3.97)^{* * *}$ & $(3.09)^{* *}$ & $(0.38)$ & 0.1765 \\
\hline Malaysia & 0.2271 & 0.1534 & 0.0017 & 0.0010 & 6471 \\
\hline & $(6.02)^{* * *}$ & $(6.13)^{* * *}$ & $(0.60)$ & $(0.50)$ & 0.0362 \\
\hline Netherlands & 0.4106 & -0.1163 & 0.0181 & 0.0058 & 2270 \\
\hline & $(7.21)^{* * *}$ & $(-3.13)$ & $(3.99)^{* * *}$ & $(2.37) * *$ & 0.1063 \\
\hline Norway & 0.3817 & 0.1571 & 0.0082 & -0.0025 & 1626 \\
\hline & $(9.03)^{* * *}$ & $(4.89)^{* * *}$ & $(2.71) * * *$ & $(-0.79)$ & 0.1974 \\
\hline New Zealand & 0.3828 & 0.0444 & 0.0022 & 0.0021 & 829 \\
\hline & $(5.11)^{* * *}$ & $(1.57)$ & $(0.43)$ & $(0.33)$ & 0.1088 \\
\hline
\end{tabular}




\begin{tabular}{|c|c|c|c|c|c|}
\hline Pakistan & $\begin{array}{c}0.6196 \\
(7.57)^{* * *}\end{array}$ & $\begin{array}{c}-0.2254 \\
(-1.54)\end{array}$ & $\begin{array}{l}0.0107 \\
(0.93)\end{array}$ & $\begin{array}{l}0.0055 \\
(1.57)\end{array}$ & $\begin{array}{c}1007 \\
0.2628\end{array}$ \\
\hline Peru & $\begin{array}{c}0.3047 \\
(3.86)^{* * *}\end{array}$ & $\begin{array}{c}-0.5953 \\
(-3.26)^{* * *}\end{array}$ & $\begin{array}{c}0.0709 \\
(4.71)^{* * *}\end{array}$ & $\begin{array}{c}0.0170 \\
(2.69)^{* * *}\end{array}$ & $\begin{array}{c}467 \\
0.2179\end{array}$ \\
\hline Philippines & $\begin{array}{l}0.1777 \\
(1.96)^{*}\end{array}$ & $\begin{array}{c}0.0992 \\
(1.61)\end{array}$ & $\begin{array}{c}0.0188 \\
(2.94)^{* * *}\end{array}$ & $\begin{array}{l}0.0048 \\
(0.89)\end{array}$ & $\begin{array}{c}1257 \\
0.0577\end{array}$ \\
\hline Portugal & $\begin{array}{c}0.2685 \\
(2.66) * * *\end{array}$ & $\begin{array}{l}0.1624 \\
(1.10)\end{array}$ & $\begin{array}{c}0.0195 \\
(2.03)^{* *}\end{array}$ & $\begin{array}{c}-0.0041 \\
(-0.54)\end{array}$ & $\begin{array}{c}824 \\
0.0658\end{array}$ \\
\hline Singapore & $\begin{array}{c}0.4891 \\
(12.33)^{* * *}\end{array}$ & $\begin{array}{c}0.0633 \\
(2.61)^{* * *}\end{array}$ & $\begin{array}{c}0.0093 \\
(1.58)\end{array}$ & $\begin{array}{c}0.0003 \\
(0.11)\end{array}$ & $\begin{array}{c}3712 \\
0.1357\end{array}$ \\
\hline Sweden & $\begin{array}{c}0.1782 \\
(3.92) * * *\end{array}$ & $\begin{array}{l}0.0159 \\
(0.64)\end{array}$ & $\begin{array}{c}-0.0071 \\
(-2.46)^{* *}\end{array}$ & $\begin{array}{c}-0.0018 \\
(-0.60)\end{array}$ & $\begin{array}{c}2777 \\
0.0347\end{array}$ \\
\hline Thailand & $\begin{array}{c}0.3126 \\
(6.73)^{* * *}\end{array}$ & $\begin{array}{c}-0.0663 \\
(-1.49)\end{array}$ & $\begin{array}{c}0.0413 \\
(3.61)^{* * *}\end{array}$ & $\begin{array}{c}0.0119 \\
(4.63)^{* * *}\end{array}$ & $\begin{array}{c}3271 \\
0.1136\end{array}$ \\
\hline Turkey & $\begin{array}{c}0.2459 \\
(3.12)^{* * *}\end{array}$ & $\begin{array}{c}-0.0509 \\
(-0.73)\end{array}$ & $\begin{array}{c}0.0206 \\
(2.83)^{* * *}\end{array}$ & $\begin{array}{c}0.0088 \\
(2.79) * * *\end{array}$ & $\begin{array}{c}1286 \\
0.0505\end{array}$ \\
\hline Taiwan & $\begin{array}{c}0.3771 \\
(11.08)^{* * *}\end{array}$ & $\begin{array}{c}0.1934 \\
(3.19)^{* * *}\end{array}$ & $\begin{array}{c}0.0452 \\
(9.26)^{* * *}\end{array}$ & $\begin{array}{c}0.0191 \\
(4.19)^{* * *}\end{array}$ & $\begin{array}{c}6564 \\
0.1224\end{array}$ \\
\hline United States & $\begin{array}{c}0.3169 \\
(35.85)^{* * *}\end{array}$ & $\begin{array}{c}0.0878 \\
(32.97)^{* * *}\end{array}$ & $\begin{array}{c}0.0176 \\
(24.42)^{* * *}\end{array}$ & $\begin{array}{c}-0.0010 \\
(-3.38)^{* * *}\end{array}$ & $\begin{array}{l}66323 \\
0.1801\end{array}$ \\
\hline South Africa & $\begin{array}{c}0.3702 \\
(9.45)^{* * *}\end{array}$ & $\begin{array}{c}-0.0239 \\
(-0.75)\end{array}$ & $\begin{array}{c}-0.0070 \\
(-2.97) * * *\end{array}$ & $\begin{array}{c}0.0063 \\
(3.36) * * *\end{array}$ & $\begin{array}{c}3065 \\
0.1025\end{array}$ \\
\hline
\end{tabular}

*,**, and ${ }^{* * *}$, significant at the 10,5 and 1 percent level, respectively. 